NASA Technical Memorandum 109115

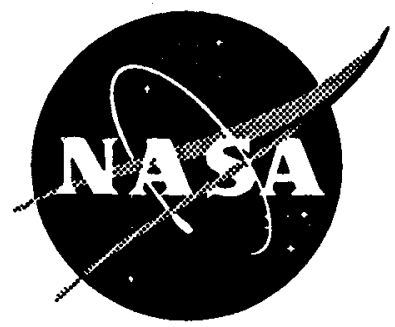

\title{
Through-the-Thickness Tensile Strength of Textile Composites
}

Wade C. Jackson

Langley Research Center, Hampton, Virginia

Peter G. Ifju

University of Florida, Gainsville, Florida

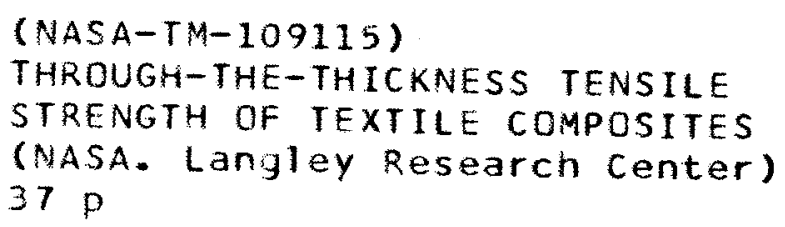

Unclas

May 1994

National Aeronautics and Space Administration Langley Research Center Hampton, Virginia 23681-0001 
ABSTRACT: A series of tests was run to characterize the through-the-thickness tensile strength for a variety of composites that included 2D and 3D braids, 2D and 3D weaves, and prepreg tapes. A new test method based on a curved beam was evaluated. The through-the-thickness deformations were characterized using moiré interferometry. Failures were significantly different between the 2D and 3D materials. The 2D materials delaminated between layers due to out-of-plane tensile stresses. The strength of the 2D textile composites did not increase relative to the tapes. The 3D materials failed due to the formation of radial cracks caused by high circumferential stresses along the inner radius. A circumferential crack similar to the $2 \mathrm{D}$ materials produced the final failure. Final failure in the 3D materials occurred at a lower bending moment than in the other materials. The early failures were caused by radial crack formation rather than a low through-the-thickness strength.

\section{Introduction}

Composites made from textile preforms are currently being evaluated for use in aircraft structures. Textile composites have the potential for significant cost savings through automated preform fabrication and low-cost resin transfer molding (RTM). Another benefit of textile composite materials is the potential for improved through-the-thickness properties. Because of relatively low interlaminar properties, traditional laminated composites are very susceptible to delamination from out-of-plane loads. Out-of-plane loads may be produced from loading such as impact loading or around structural details such as curved geometry, ply drops, or fasteners. With improved through-the-thickness properties, the susceptibility to damage from outof-plane loads should be greatly reduced.

Composites made from textile preforms are expected to improve both the through-the-thickness tensile and shear strengths. Textile composites may be 2D where discrete layers are stacked or 3D where the preform is a single layer with 
through-the-thickness reinforcement. In 2D materials, the preform layers are expected to nest snugly together to improve the through-the-thickness properties. In the $3 D$ materials, direct reinforcement in the thickness direction was specifically included to directly improve these properties. Although the through-the-thickness tensile strength is an important material property for design purposes, it inherently is a difficult property to quantify. In laminated composite materials, the through-the-thickness tensile strength can be approximated by the transverse-width strength measured from flat $90^{\circ}$ specimens [1]. In textile composites, however, the architecture of the preform is three dimensional with significantly different properties in all directions.

Several through-the-thickness test methods have been proposed. In Ref 2, a flatwise tension test was investigated where the specimen was loaded using aluminum shanks bonded to the upper and lower surfaces of the specimen. A radius was machined into the specimen to give a minimum area at the center. This type of test method was not used because failures were often at the bondline and the test required thick specimens and extensive machining. Other test methods have been evaluated which use " $L$ " or "C" shaped specimens $[1,3,4]$. This methodology incorporates a specimen with a curved test section. Through-the-thickness tension is induced in the test section by a moment which attempts to open the curve. A throughthe-thickness tensile failure is produced around the angle. In Ref 1, a test configuration was used where a hinged loading mechanism was clamped on to each loading arm of an "L" shaped specimen. Due to the loading configuration, the stresses were difficult to calculate and varied with angular position within the curved region. In addition, the hinged mechanism required laborious positioning and aligning. Consequently, a new test methodology was developed which used a four-pointbending fixture with the "L" shaped specimen. Since the bending moment was created by a couple on each loading arm, a state of pure bending was produced in the test section. This method has several advantages over the other methods: simplified 
analysis, stresses independent of angular position, constant moment in the test section, and a self-aligning test configuration. To evaluate this new test method, strengths were measured using the four-point-bend method and the hinge loading method of Ref 1.

Using these two test methods, a series of tests was run to characterize the through-the-thickness strength for a variety of composites made from textile preforms. Specimens were made from four different 2D braids, a 3D braid, six 3D weaves, and from prepreg fabrics. Unidirectional tape specimens made from toughened epoxy (AS4/8551-7) and untoughened epoxy (AS4/3501-6) were also tested. For both loading configurations, the data were reduced using an elasticity solution for anisotropic curved beams.

Textile composites have very inhomogeneous properties due to their coarse preform architectures. Consequently, very nonuniform displacement fields were expected both in plane and through the thickness. The geometry of the preform can be broken down into fundamental repeated building blocks called unit cells. A sensitivity study was performed to determine the effect of material unit cell size relative to specimen width. A certain number of unit cells may be required across the width to insure a representative failure mode. To study the through-the-thickness deformations, moiré interferometry was used to determine the displacement fields along the edge of the test section. Moiré was also used to obtain the strains from a unidirectional laminate for comparison to analytical predictions.

\section{Materials}

Curved test specimens were manufactured with five different fiber architectures: tape, 2D-woven fabrics, 3D weaves, 2D braids, and a 3D braid. All materials were manufactured from the same fiber (Hercules AS4 carbon fiber) and similar resins. The tape and 2D-woven fabric were both prepreg materials of Hercules AS4/3501-6. A 
toughened epoxy tape (Hercules AS4/8551-7) was also included for comparison. The braided and woven preforms were impregnated with Shell RSL-1895/W epoxy resin using the resin transfer molding (RTM) process. The 1895/W system was developed for RTM and has similar properties to 3501-6 epoxy. A detailed description of the preform materials and the specific RTM process is contained in Ref 5.

Each material was used to manufacture a $300-\mathrm{mm}$-wide "L" shaped panel with a $5.08-\mathrm{mm}$ inner radius at the bend. The specimens that were made from the prepreg material were laid up on the radiused corner of a solid aluminum block and then cured on that block. The specimens that were manufactured using RTM were bent to match the curved shape of the mold from a flat mat. Consequently, the architectures of the preforms were distorted at the bend. The spacing between the two halves of the mold was fixed to form a panel with a uniform thickness of $6.35 \mathrm{~mm}$. The 3D braid was thinner than the other preforms and was shimmed around the outer radius to form a thickness of $3.00 \mathrm{~mm}$.

Unidirectional tape laminates were made with AS4/3501-6 and with AS4/8551-7. A 24- and a 48-ply panel were made from each material. Due to a manufacturing error, the 8551-7 panel actually contained 25 plies. The 2D-woven fabrics included a plain weave and two 5 -harness satin weaves. One of the 5 -harness satin weaves was made with $3 \mathrm{k}$ tows (AW280-5H), and one was made with $6 \mathrm{k}$ tows (AW370-5H). The plain weave (AW193PW) was used to make two panels of 12 and 16 layers. The panels made from the satin weaves were 12 layers thick. These fabric panels were manufactured such that the circumferential tows on the roll corresponded to the circumferential plies in the curved region. In several panels, the thickness in the bend was greater than in the loading arms due to the use of a single male tool.

The 2D braids were formed on cylindrical mandrels and incorporated longitudinal yarns to create a triaxial construction with a $0^{\circ} \pm \theta^{\circ}$ orientation (Fig. 2). Four different braid geometries were manufactured and are summarized in Table 1. 
The braid angle, the yarn sizes, and the longitudinal yarn content were varied to determine sensitivity to these parameters. The unit cell size, also listed in Table 1 , varied significantly with these parameters. A representative unit cell is outlined in Fig. 2. The desired thickness was obtained by overbraiding layers. Since all specimens had the same nominal thickness of $6.35 \mathrm{~mm}$, the number of layers decreased with increasing yarn bundle size. Photomicrographs showing through-the-thickness cross sections indicated that the layers of material had nested and the unit cells of material were offset from layer to layer. Prior to the RTM process, the braids were slit longitudinally from the mandrel, laid flat, and stitched around the perimeter to form a flat mat. The 3D braid was formed on a Cartesian braiding bed where each yarn carrier moved in a predetermined path about the bed resulting in a continuously interlaced fiber structure.

The 3D weaves were all interlock woven fabrics where yarns are woven through the thickness to provide direct resistance to delamination. The interlock tows ran parallel to the warp $\left(0^{\circ}\right)$ yarns and wrapped around the weft $\left(90^{\circ}\right)$ yarns. Three different weave architectures were investigated: through-the-thickness orthogonal interlock (OS), through-the-thickness angle interlock (TS), and layer-to-layer angle interlock (LS). The weave architectures are summarized in Table 2 and are shown schematically in Fig. 2. For each architecture, one panel was woven using small fiber bundles, and one panel was woven using large fiber bundles.

\section{Specimen Conflgurations, Test Procedures, and Data Reduction}

Specimens were generally cut into $25-\mathrm{mm}$ widths from the $300-\mathrm{mm}$-wide panels. In several panels, specimen widths were varied to investigate the effects of specimen width relative to unit cell width. The width and radial thickness of each specimen were measured using a vernier caliper. Two different test configurations, shown in Fig. 1 and schematically in Fig. 3, were used to measure strength. A new test 
method was evaluated which used a four-point-bending (4PB) fixture. The specimens were loaded by rollers which created a force couple on each loading arm. The $9.52-$ mm-diameter rollers had a fixed horizontal distance between rollers, $d_{x}$, of $12.84 \mathrm{~mm}$. Because of the geometry of the 4PB fixture, the specimens were self aligning. The second configuration used a steel hinged loading mechanism (HLM) which was aligned and clamped on to the specimen's loading arms. This test method was used in Ref 1 to measure the strength of unidirectional laminates. The loading fixture allowed the specimen to be tested in a tension testing machine. The loading arm length, $L$, was $25.4 \mathrm{~mm}$, and the loading pin offset, $\delta$, was $4.32 \mathrm{~mm}$. The displacement was controlled at $0.5 \mathrm{~mm} / \mathrm{min}$ during loading for both test methods. Loads and displacements were digitally recorded. To aid in detecting failure location, the edges of the specimen were painted white with a water-based typewriter correction fluid.

The loads on the test section were calculated for both test configurations for later analysis. Referring to Fig. $3 a$ and the 4PB configuration, the applied moment on the curved section of the specimen is simply the product of the force exerted by one of the cylindrical loading bars, $P_{b}$, and the distance, $L$, between two bars along a loading arm. The bar force and distance were calculated from the total load, $P$, and the geometries of the loading fixture and test specimen.

$$
M=P_{b} L=\left(\frac{P}{2 \cos (\phi)}\right)\left(\frac{d_{r}}{\cos (\phi)}+(D+t) \tan (\phi)\right)
$$

The final moment calculation is given in Eq 1 where $\phi$ is the angle of the loading arm from horizontal, $d_{x}$ is the horizontal distance between the centerlines of two adjacent rollers, $D$ is the diameter of the cylindrical loading bars, and $t$ is the specimen thickness. Since a force couple acts on the loading arm, the resultant force is zero. 
For the HLM test configuration, a similar procedure was followed to calculate the loading and is detailed in Ref 1 . The resultant force, however, is nonzero for this case.

Since $\phi$ can change significantly during loading, the value of $\phi$ at failure was used to obtain a more accurate value of the applied moment. In order to calculate $\phi$ during loading, the vertical distance, $d_{y}$, between the cylindrical loading bars was calculated by subtracting the vertical displacement, $\Delta$, of the loading fixture from the initial value of $d_{y}$ (Eq 2).

$$
d_{y}=d_{x} \tan \left(\phi_{i}\right)+\frac{D+t}{\cos \left(\phi_{i}\right)}-\Delta
$$

The vertical displacement, $\Delta$, was obtained from the stroke output of the test stand. The initial value of $d_{y}$ was calculated from the initial angle, $\phi_{l}$, and the loading geometry. The initial angle, $\phi_{l}$, was obtained by measuring the overall angle between the loading arms of the specimen prior to testing. Using trigonometric functions, a relationship was then derived for the value of $\phi$ for a given value of $d y$.

$$
\phi=\sin ^{-1}\left(\frac{-d_{x}(D+t)+d_{y} \sqrt{d_{x}^{2}+d_{y}^{2}-D^{2}-2 D t}}{d_{x}^{2}+d_{y}^{2}}\right)
$$

All other parameters in Eq 4 remain fixed during loading.

One specimen of each architecture was analyzed using moiré interferometry to study and document the deformation characteristics. Using this full field optical technique, both horizontal and vertical displacement information were obtained in the form of fringe patterns [6]. Strains could then be calculated from the displacement patterns. A crossed line diffraction grating with 2400 lines $/ \mathrm{mm}$ was replicated on the edge of the specimens. Since the gratings were thin and compliant, they deformed freely on the loaded specimens. The sensitivity to displacements was $0.416 \mu \mathrm{m}$ per 
fringe. A camera focused on the specimen surface captured the interference fringe patterns in $220 \mathrm{~N}$ load steps until failure. All the moire tests were run in the 4PB fixture.

\section{Analysis}

\section{Stress Equations}

Solutions were developed by Lekhnitskii [6] for the stresses in a curved beam segment with cylindrical anisotropy. To apply these stress equations, the applied loads had to be translated to the ends of the curved segment. For the hinged test configuration, the force translation results in both a force and a moment applied to the ends of the segment. Consequently, the stress equations become more complex since the stresses produced by the moment and the end force have to be superimposed. Also, because of the end force, the stresses become a function of angular position, $\theta$, shown in Fig $3 \mathrm{~b}$. However, in the four-point-bending test configuration, the curved segment is under a state of pure bending. Consequently, the closed-form stress analysis is much simpler and independent of angular position. The plane stress equations are given by Eqs. 4-7 for a curved beam under pure bending.

$$
\begin{gathered}
\sigma_{r}=-\frac{M}{r_{o}^{2} w g}\left[1-\frac{1-\rho^{\kappa+1}}{1-\rho^{2 \kappa}}\left(\frac{r}{r_{o}}\right)^{\kappa-1}-\frac{1-\rho^{\kappa-1}}{1-\rho^{2 \kappa}} \rho^{\kappa+1}\left(\frac{r_{o}}{r}\right)^{\kappa+1}\right] \\
\sigma_{\theta}=-\frac{M}{r_{o}^{2} w g}\left[1-\frac{1-\rho^{\kappa+1}}{1-\rho^{2 \kappa}} \kappa\left(\frac{r}{r_{o}}\right)^{\kappa-1}+\frac{1-\rho^{\kappa-1}}{1-\rho^{2 \kappa}} \kappa \rho^{\kappa+1}\left(\frac{r_{o}}{r}\right)^{\kappa+1}\right] \\
\tau_{r \theta}=0
\end{gathered}
$$

where 


$$
g=\frac{1-\rho^{2}}{2}-\frac{\kappa}{\kappa+1} \frac{\left(1-\rho^{\kappa+1}\right)^{2}}{1-\rho^{2 \kappa}}+\frac{\kappa \rho^{2}}{\kappa-1} \frac{\left(1-\rho^{\kappa-1}\right)^{2}}{1-\rho^{2 \kappa}}, \kappa=\sqrt{\frac{E_{\theta}}{E_{r}}}, \rho=\frac{r_{i}}{r_{o}}
$$

and the symbols are defined as:

$$
\begin{aligned}
E_{r_{1}} E_{\theta} & =\text { Moduli in the radial and tangential directions, respectively } \\
r, \theta & =\text { Cylindrical coordinates of any point in the curved segment } \\
r_{i}, r_{\theta} & =\text { Inner and outer radii of curved segment } \\
w & =\text { Width of the specimen } \\
\sigma_{r}, \sigma_{\theta}, \tau_{r \theta} & =\text { Stress components in curved segment }
\end{aligned}
$$

By using Eq 4 and the moment calculated from Eq 1, the maximum radial stress for the 4PB test was determined. A similar procedure, outlined in Ref 1 , was used to obtain . the maximum stresses for the HLM test

\section{Comparison of Test Methods}

The stress field produced in the curved region is slightly different for the two different loading methods. The 4PB stress field is produced solely by a bending moment while the HLM stress field is made up of two components that are produced by a moment and by an end force. The presence of the end force slightly alters the overall stress field. A comparison of the two radial and tangential stress distributions, $\sigma_{\mathrm{r}}$ and $\sigma_{\theta}$, along a the centerline of the specimen are shown in Figs. 4-5. For comparison purposes, the 4PB stresses were scaled by a factor of 0.608 to produce equal maximum radial stresses for the two loading techniques. Also shown, for the HLM stresses, are the two components (dashed lines) that were added to produce the total stress. The overall radial stress distributions are very similar for the two loading cases. As expected, the radial and tangential stress components produced by the moment in the HLM loading are directly proportional to the total stresses in the 4PB 
loading. The radial stress component produced by the end force reaches a maximum closer to the inner radius. Consequently, the overall peak stress location moves slightly towards the inner radius for the HLM case. For the example shown, the peak stress location moved from $35 \%$ of thickness to $31 \%$. For equal values of maximum radial stress, the tangential stress for the HLM loading was slightly higher along the inner radius. The neutral axis also shifted slightly towards the outer radius in the HLM loading due to the effects of the end force.

The radial stress produced by the HLM method peaks on the centerline (i.e., $\theta=$ $\left.45^{\circ}\right)$. The maximum stresses at the ends of the curved section were $12 \%$ and $16 \%$ lower than at the centerline for specimen thicknesses of $3.18 \mathrm{~mm}$ and a $6.35 \mathrm{~mm}$, respectively. The radial stress produced by the 4PB method, however, remains constant around the curve. Consequently, specimens tested using the 4PB test may have slightly lower strengths since more material is under high stress than in the HLM test.

\section{Results and Discussion}

\section{Failure}

Each specimen was loaded to failure using either the four-point-bending fixture or the hinged loading mechanism. Failures were significantly different between the 2D and 3D materials. The moiré fringe patterns provided an excellent method of detecting and documenting damage. The cracks were easily recognizable with the aid of the fringe patterns. Moiré fringe patterns are shown in Figs. 6-8 for a 48-ply AS4/3501-6 tape specimen, a 2D triaxial $\left[0_{6 \mathrm{k}} / \pm 45_{15 \mathrm{k}}\right]_{10}$ braid, and a 3D OS-1 weave, respectively. The horizontal $\mathrm{U}$ - and vertical $\mathrm{V}$-displacement fields prior to failure and the $\mathrm{V}$ field after failure are shown. In general, the fringe density increases in areas of high strain. As evidenced by the patterns, the displacement fields are markedly different for the three specimens. 
All the 2D materials (tapes, fabrics, and triaxial braids) simply delaminated between layers due to the out-of-plane tensile stresses. The delamination ran unstably around the bend and resulted in a sharp load drop and an audible pop. No damage was detected prior to delamination. Often, subsequent delaminations were also formed due to the load redistribution into the sublaminates. For the tape specimen, the V-displacement field consisted of relatively evenly spaced horizontal fringes in the central region of the test section (Fig. 6). This pattern indicates a uniform displacement field through the thickness in this region. The $U$ field shows the circumferential strains changing from tension in the inner radius to compression along the outer radius. The star pattern occurs near the center of bending. The wavy fringes are a result of shear deformation between plies. At failure, three delaminations were formed which extend into the arms of the specimen. Because of the near simultaneous formation of the delaminations, the initial delamination could not be determined.

For the 2D triaxial braid, the wavy fringes in the $U$ field indicate a significant amount of shear deformation between layers (Fig. 7). The star pattern, where strains go from compression to tension, is very near the inner radius. The $V$ field shows a very inhomogeneous displacement field due to the coarse fiber architecture. The displacement fields may be significantly influenced by free edge stresses generated by the termination of off-axis fibers at the edge. At failure, circumferential cracks formed between braided layers resulting in multiple delaminations. The delaminations in the 2-D braids often followed a tortuous path due to the nested layers. Many of the cracks appear to correspond to regions of high shear deformation which were observed in the $U$ field.

In the 3D materials (weaves and braid), damage began accumulating very early in the loading. During loading, the specimens emitted a crackling noise. The crackling noise was produced by radial cracks forming in the inner radius caused by 
the tensile circumferential stress. In the 3D weaves, the radial cracks extended across the entire width of the specimen. Some of the radial cracks extended a third of the way into the thickness. A crack can be easily seen in both displacement fields of the OS-1 weave (Fig. 8). The presence of this crack greatly affects the entire deformation field. The region containing the crack is essentially undeformed while the region above the crack deforms similarly to an uncracked specimen. The post failure $V$ field shows the circumferential cracks that caused the final failure. Despite the through-the-thickness reinforcement, a circumferential cracks similar to the 2D materials eventually formed. The OS-2 weave, however, never formed a circumferential crack. In the OS weaves, the through-the-thickness yarns were normal to the plane containing the warp and weft yarns. The OS-2 weave had a greater density of through-the-thickness yarns than the OS-1 weave which did not prevent circumferential cracking. Since the cracks in the inner radius significantly alter the stresses in the bend, a through-the-thickness stress at failure could not be calculated for the 3D materials.

\section{Strain Distribution}

The strain distribution from Fig. 6 was extracted from the fringe patterns and is plotted as symbols in Fig. 9. The different symbols for the radial strain distribution represent strains obtained from either the light field or the dark field. The predicted

strains from the elasticity solution are plotted as a line. Both the radial (through-thethickness) strain, $\varepsilon_{r}$, and the circumferential strain, $\sigma_{\theta}$, are shown. The maximum tensile through-the-thickness strain is located near the center of the test section. The through-the-thickness moire strains are slightly higher than the predicted values. The differences between the experimental and predicted values were attributed to a distortion of the outer radius of test section during the specimen's manufacture. In addition, the local ply thicknesses gradually increase from the inner radius to the outer radius. Consequently, the center of bending shifts towards the inner radius due to the 
corresponding stiffness change. For coarse architectures, the spatial resolution of the moiré interferometry was too low to adequately characterize the deformations around the fiber bundles. Consequently, for the textile geometries, the fringe patterns were used in a qualitative manner only.

\section{Effect of Unit Cell Size}

Several specimen widths were tested to study the effects of specimen width relative to unit-cell width. A small number of unit cells across the width may cause unrepresentative failure modes or a change in strength. Small strength differences between different width specimens, however, may result because of volumetric effects. Strength should naturally decrease with an increasing volume of stressed material. Consequently, a volumetric scaling law based on Weibull statistics [7] was used to eliminate volumetric effects from the data (Eq 8).

$$
\frac{\left(\sigma_{u t t}\right)_{1}}{\left(\sigma_{u t}\right)_{2}}=\left(\frac{\left(V_{2}\right)}{\left(V_{1}\right)}\right)^{1 / m}
$$

Since the through-the-thickness strength is matrix dominated, a shape parameter, $m$, of 7.63 which was obtained from a series of tensile tests of $90^{\circ}$ AS4/3501-6 laminates was used [8].

Failure modes did not change as the ratio of specimen width to unit cell width was varied. The scaled and unscaled strengths, coefficient of variation, and the ratio of specimen width to unit-cell width are listed in Table 3. Each strength value represents the maximum radial stress at the onset of damage for a minimum of three tests. Based on this scaling law, a strength reduction of $8.7 \%$ was expected as a result of doubling the stressed volume. On average, the strength was reduced by $7.3 \%$ for the materials shown in the table. In general, the data sets with large coefficients of 
variation showed the largest difference in scaled strengths. However, with the exception of the $\left[0_{30 \mathrm{k}} / \pm 70_{6 \mathrm{k}}\right]_{8}$ braid, the scaled averages for each material system were extremely close (within 15\%) given the overall data scatter. The strength was apparently unaffected by various ratios of specimen width to unit-cell width. All strength variations were consistent with volumetric effects or scatter. Even the strengths of the $12.7-\mathrm{mm}$ wide $\left[0_{75 \mathrm{k}} / \pm 70_{15 \mathrm{k}}\right]_{6}$ braid specimens, which were only onehalf of a unit cell wide, were unaffected. Since the volumetric scaling law appeared to correctly scale for different width specimens, all specimens were scaled to $25.4-\mathrm{mm}$ widths and combined for comparison purposes.

\section{Comparison of Test Methods}

Specimens taken from the same panel were tested using both test methods to determine the effects on strength. A comparison of strengths measured using the two different test methods is shown in Fig. 10 for seven panels which represent all the 2D material types. The range of strengths, indicated by symbols, is also shown in the figure. The average strengths, number of specimens, and the coefficient of variation are listed in Table 4. For most of the materials, the average strengths were quite close considering the scatter in the data. Some differences may arise because of variations in specimen quality since specimens for each test method came from opposite sides of the same panel. Consequently, if the quality of the panel varied from side to side, a disparity in strengths would be exhibited between the two test methods. In the 16layer plain weave panel, the two adjacent specimens that were tested using different test methods had identical strengths yet the overall averages differed by $24 \%$. Also, less scatter was expected using the 4PB test since the specimens were self aligning while, in the HLM test, the hinges must be precisely positioned by hand. However, the scatter in the data was similar between the two methods. Since no significant 
differences were demonstrated, the strength data from the two test methods were combined.

\section{Strength of $2 D$ Materials}

A summary of the average strengths (maximum $\sigma_{r}$ at the onset of damage) along with the high/low data is shown in Fig. 7 for all the 2D materials. These data are also listed in Table 5 with the number of tests and the coefficient of variation. In general, the 2D textile materials had very similar strengths with the range of strengths overlapping for each of the material systems. However, the through-the-thickness strength was lower than the tape materials. The 48-ply AS4/3501-6 tape material had a similar strength to the $2 \mathrm{D}$ textiles but had a low fiber volume fraction. The other tape specimens, however, had significantly higher strengths. The through-the-thickness

strengths of the prepreg materials, and possibly the RTM materials, decreased rapidly with decreasing fiber volume fraction.

The average strength of the 24-ply AS4/3501-6 tape was approximately $20 \%$ higher than the transverse-width strength measured from flat $90^{\circ}$ specimens [8]. Due to volumetric effects, the strength measured from a curved beam should be higher due to the smaller volume of stressed material. The 24-ply strength was significantly higher than the 48-ply strength. Excluding volumetric effects, the through-thethickness strength should be independent of thickness. The average ply thickness in the bend was $0.165 \mathrm{~mm}$ in the 48-ply specimens and $0.133 \mathrm{~mm}$ in the 24-ply specimens. In Ref 1, a strong correlation was found between ply thickness and strength. Therefore, the large strength difference may be a result of the $24 \%$ increase in ply thickness. The average ply thicknesses of the 25 and 48-ply AS4/8551-7 specimens were nearly identical at 0.157 and $0.156 \mathrm{~mm}$, respectively. Accordingly, the strengths were also close and within the scatter of data. The manufacturer's product data sheet for AS4/3501-6 lists a ply thickness of $0.13 \mathrm{~mm}$ to achieve a $62 \%$ 
fiber volume fraction. Since the AS4/3501-6 and AS4/8551-7 materials had identical fiber areal weights $\left(149 \mathrm{~g} / \mathrm{m}^{2}\right)$, identical ply thicknesses represent identical fiber volume fractions. Consequently, the strengths between the two material systems were only compared for similar fiber volume fractions. The average ply thicknesses of the 48-ply 3501-6 specimens and all the $8551-7$ specimens were within $6 \%$. For this case, the 8551-7 has nearly twice the strength than of the 3501-6 material.

The strengths of the 12- and 16-layer plain weaves were nearly identical. The average layer thickness in the bend was $0.208 \mathrm{~mm}$ for both thicknesses. The average layer thicknesses in the loading arms were 0.180 and $0.178-\mathrm{mm}$ for the 12- and 16layer specimens, respectively. The manufacturer's product data sheet lists a ply thickness of $0.18 \mathrm{~mm}$ for a $62 \%$ fiber volume fraction. Therefore, these strengths may increase with higher compaction. The two $5 \mathrm{H}$-satin weaves also had nearly identical strengths. For the weave with $3 k$ tows, the average layer thickness was $0.301 \mathrm{~mm}$ in the bend whereas the product data sheet lists a thickness of $0.25 \mathrm{~mm}$ for a $62 \%$ fiber volume fraction. For the weave with $6 \mathrm{k}$ tows, the average layer thickness was 0.347 $\mathrm{mm}$ in the bend and the corresponding value on the data sheet was $0.34 \mathrm{~mm}$ for a $62 \%$ fiber volume fraction. Therefore, for equal fiber volume fractions, the $3 \mathrm{k}$ weave may have a higher strength. The $2 \mathrm{D}$ triaxial braids all had similar strengths. The $0 / \pm 70^{\circ}$ braid with the $75 \mathrm{k}$ axial tows had a slightly lower average than the other three braids. The coefficients of variation were consistent with the prepreg materials.

\section{Strength of $3 D$ Materials}

Since stresses in a damaged material cannot be readily calculated, the moment at failure was calculated for the 3D materials. The failure load was defined as the load where circumferential cracks formed. The circumferential cracks caused a small drop in load and reduced the bending stiffness. The average bending moment at failure is shown in Fig. 8 and listed in Table 6 for tests using the four-point-bend fixture. Many of 
the 2D materials are also included for comparison. The OS-2 weave is not shown since circumferential cracks did not form. The bending moment was normalized by the width and thickness of each specimen for comparison. The 3D materials all failed at significantly lower bending moments than all of the 2D materials. The 3D architecture failed at lower loads due to the radial cracking along the inner radius. For the six 3D weave architectures, the bending moments at failure were all within $20 \%$ of each other. The bending moment of the 3D braid was approximately $30 \%$ lower than the 3D weaves. When analyzed in terms of the bending moment, the 2D materials had relative rankings nearly identical to the strength analysis.

\section{Concluding Remarks}

Curved beams made from a variety of $2 \mathrm{D}$ and $3 \mathrm{D}$ composites were tested to determine the through-the-thickness strength. The 2D materials included four triaxial braids, three prepreg fabrics, and two prepreg tapes. The 3D materials included a braid and six interlock weaves. A new test configuration that used a four-pointbending fixture was evaluated and compared to a configuration that used a hinged loading mechanism. Both test methods produced identical failures at nearly identical stresses. However, the four-point-bend test method was the preferred test method since it was self-aligning and did not require laborious positioning and clamping of hinges onto the specimen.. In addition, the strength analysis was greatly simplified since a constant moment was produced in the test section. Moiré interferometry was successfully used to study the edge deformations and to highlight crack formations.

Failures were significantly different between the 2D and 3D materials. The 2D materials delaminated between layers due to out-of-plane tensile stresses. At failure, the sublaminates formed by the initial delamination would often delaminate to form more sublaminates. The delaminations between braided layers followed a more tortuous path than the other 2D materials. Initial damage in the 3-D braids occurred 
very early in the loading and was made up of a series of radial cracks caused by the tensile circumferential stress along the inner radius. Final failure was caused by the formation of circumferential cracks around the test section similar to the 2D materials. Circumferential cracks did not form in the OS-2 weave. Due to the radial cracks, a through-the-thickness strength could not be calculated for the 3D materials.

The strength of the 2D textile composites was lower than the tapes. The through-the-thickness strength was found to decrease significantly with decreasing fiber volume fractions. The size of the unit cell relative to the specimen width did not affect the strength or the failure mode. Final failure in the 3D materials occurred at a lower bending moment than the other materials. The early failures were caused by the formation of radial cracks due to bending rather than a lower through-the-thickness strength.

\section{References}

[1] Jackson, W. C. and Martin, R. H., "An interlaminar Tensile Strength Specimen," Composite Materials: Testing and Design (Eleventh Volume), ASTM STP 1206, E. T. Camponeschi, Jr., Ed., American Society for Testing and Materials, Philadelphia, December 1993, pp. 333-354.

[2] Lagace, P.A. and Weems, D.B., "A Through-the-Thickness Strength Specimen for Composites," Test Methods for Design Allowables for Fibrous Composites: 2nd Volume, ASTM STP 1003, C.C. Chamis, Ed., American Society for Testing and Materials, Philadelphia, 1989, pp. 197-207.

[3] Hiel, C.C., Sumich, M., and Chappell, D.P., "A Curved Beam Test Specimen for Determining the Interlaminar Strength of a Laminated Composite," Journal of Composite Materials, Vol. 25, July 1991, pp. 854-868.

[4] Martin, R. H., "Delamination Failure in a Unidirectional Curved Composite Laminate," Composite Materials: Testing and Design (Tenth Volume), ASTM 
STP 1120, Glenn C. Grimes, Ed., American Society for Testing and Materials, Philadelphia, 1992, pp. 365-383.

[5] Falcone, A., Dursch, H, Nelson, and Avery, W., "Resin Transfer Molding of Textile Composites," NASA CR 191505, July 1993.

[6] Post, D., "Moiré Interferometry," Handbook of Experimental Mechanics, A. S. Kobayashi, Ed, Prentice Hall, Englewood Hills, NJ, 1987.

[6] Lekhnitskii, S.G., "Anisotropic Plates," Gordon and Breach Science Publishers, New York, 1968, pp. 95-101.

[7] Weibull, W., "A Statistical Theory of the Strength of Materials," Ing. Vetenskaps Akad. Handl., Royal Swedish Institute Engineering Research Proceedings, NR151, 1939.

[8] O'Brien, T.K. and Salpekar, S.A., "Scale Effects on the Transverse Tensile

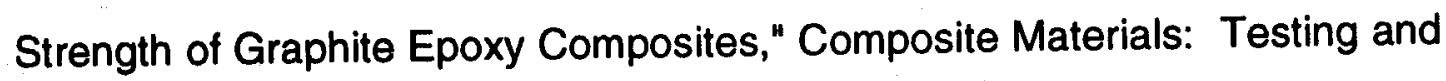
Design (Eleventh Volume), ASTM STP 1206, E. T. Camponeschi, Jr., Ed., American Society for Testing and Materials, Philadelphia, December 1993, pp. 23-52. 
TABLE 1--Characteristics of $2 D$ triaxial braids.

\begin{tabular}{ccccccc}
\hline Designation & $\begin{array}{c}\text { Braid } \\
\text { pattern }\end{array}$ & $\begin{array}{c}\text { Braider } \\
\text { size }\end{array}$ & $\begin{array}{c}0^{\circ} \text { yarn } \\
\text { size }\end{array}$ & $\begin{array}{c}\% 0^{\circ} \\
\text { yarns }\end{array}$ & $\begin{array}{c}\text { Number } \\
\text { of layers }\end{array}$ & $\begin{array}{c}\text { Unit Cell } \\
\text { size, mm }\end{array}$ \\
\hline$\left[0_{30 k} / \pm 70_{6 \mathrm{k}}\right]_{8}$ & $0 / \pm 70^{\circ}$ & $6 \mathrm{k}$ & $30 \mathrm{k}$ & 46 & 8 & $11.7 \times 2.3$ \\
{$\left[0_{75 \mathrm{k}} / \pm 70_{15 \mathrm{k}}\right]_{6}$} & $0 / \pm 70^{\circ}$ & $15 \mathrm{k}$ & $75 \mathrm{k}$ & 46 & 6 & $24.1 \times 4.3$ \\
{$\left[0_{36 \mathrm{k}} / \pm 45_{15 \mathrm{k}}\right]_{6}$} & $0 / \pm 45^{\circ}$ & $15 \mathrm{k}$ & $36 \mathrm{k}$ & 46 & 6 & $11.6 \times 5.0$ \\
{$\left[0_{6 \mathrm{k}} / \pm 45_{15 \mathrm{k}}\right]_{10}$} & $0 / \pm 45^{\circ}$ & $15 \mathrm{k}$ & $6 \mathrm{k}$ & 12 & 10 & $11.6 \times 5.5$ \\
\hline
\end{tabular}

TABLE 2--Characteristics of 3D weaves.

\begin{tabular}{|c|c|c|c|c|c|c|}
\hline \multirow[b]{2}{*}{ Code } & \multirow[b]{2}{*}{ Weave type } & \multicolumn{2}{|c|}{ Warp } & \multicolumn{2}{|c|}{ Weft } & \multirow{2}{*}{$\begin{array}{c}\text { Weaver } \\
\text { size }\end{array}$} \\
\hline & & $\#$ & size & \# & size & \\
\hline $\begin{array}{l}\text { OS-1 } \\
\text { OS-2 }\end{array}$ & Through-the-thickness orthogonal interlock & $\begin{array}{l}4 \\
6\end{array}$ & $\begin{array}{l}24 k \\
12 k\end{array}$ & $\begin{array}{l}5 \\
7\end{array}$ & $\begin{array}{l}12 k \\
6 k\end{array}$ & $\begin{array}{l}6 k \\
3 k\end{array}$ \\
\hline $\begin{array}{l}\text { TS-1 } \\
\text { TS-2 }\end{array}$ & Through-the-thickness angle interlock & $\begin{array}{l}4 \\
6\end{array}$ & $\begin{array}{l}24 k \\
12 k\end{array}$ & $\begin{array}{l}5 \\
7\end{array}$ & $\begin{array}{l}12 k \\
6 k\end{array}$ & $\begin{array}{l}6 k \\
3 k\end{array}$ \\
\hline $\begin{array}{l}\text { LS-1 } \\
\text { LS-2 }\end{array}$ & Layer-to-layer angle interlock & $\begin{array}{l}4 \\
6\end{array}$ & $\begin{array}{l}24 k \\
12 k\end{array}$ & $\begin{array}{l}5 \\
7\end{array}$ & $\begin{array}{c}12 k \\
6 k\end{array}$ & $\begin{array}{l}6 k \\
3 k\end{array}$ \\
\hline
\end{tabular}


TABLE 3--Effect of specimen width on strength.

\begin{tabular}{|c|c|c|c|c|c|}
\hline Material & $\begin{array}{l}\text { Nominal } \\
\text { width } \\
(\mathrm{mm})\end{array}$ & $\begin{array}{l}\text { Width to } \\
\text { unit cell } \\
\text { Width }\end{array}$ & $\underset{\%}{\text { C.V. }}$ & $\begin{array}{c}\text { Unscaled } \\
\text { strength, } \\
\mathrm{MPa}\end{array}$ & $\begin{array}{c}\text { Scaled } \\
\text { strength, } \\
\text { MPa }\end{array}$ \\
\hline 24-ply AS4/3501-6 & $\begin{array}{l}12.7 \\
25.4\end{array}$ & $\begin{array}{l}\ldots \\
\ldots\end{array}$ & $\begin{array}{l}12.4 \\
18.9\end{array}$ & $\begin{array}{l}74.4 \\
66.0\end{array}$ & $\begin{array}{l}68.1 \\
66.0\end{array}$ \\
\hline 48-ply AS4/3501-6 & $\begin{array}{l}12.7 \\
25.4\end{array}$ & $\begin{array}{l}\ldots \\
\ldots\end{array}$ & $\begin{array}{l}36.0 \\
13.6\end{array}$ & $\begin{array}{l}28.6 \\
22.5\end{array}$ & $\begin{array}{l}26.2 \\
22.6\end{array}$ \\
\hline 12-layer plain weave & $\begin{array}{l}12.7 \\
25.4\end{array}$ & $\begin{array}{l}2.9 \\
5.8\end{array}$ & $\begin{array}{l}4.7 \\
8.1\end{array}$ & $\begin{array}{l}26.4 \\
25.5\end{array}$ & $\begin{array}{l}24.2 \\
25.5\end{array}$ \\
\hline 16-layer plain weave & $\begin{array}{l}12.7 \\
25.4\end{array}$ & $\begin{array}{l}2.9 \\
5.8\end{array}$ & $\begin{array}{l}27.5 \\
12.7\end{array}$ & $\begin{array}{l}25.2 \\
24.5\end{array}$ & $\begin{array}{l}23.0 \\
24.5\end{array}$ \\
\hline 12 -layer $5 \mathrm{H}$ weave $(3 \mathrm{k})$ & $\begin{array}{l}12.7 \\
25.4\end{array}$ & $\begin{array}{l}1.7 \\
3.4\end{array}$ & $\begin{array}{l}15.5 \\
17.5\end{array}$ & $\begin{array}{l}37.3 \\
35.3\end{array}$ & $\begin{array}{l}34.1 \\
35.3\end{array}$ \\
\hline 12 -layer $5 \mathrm{H}$ weave $(6 \mathrm{k})$ & $\begin{array}{l}12.7 \\
25.4\end{array}$ & $\begin{array}{l}1.1 \\
2.2\end{array}$ & $\begin{array}{c}6.7 \\
18.3\end{array}$ & $\begin{array}{l}33.9 \\
34.6\end{array}$ & $\begin{array}{l}31.0 \\
34.6\end{array}$ \\
\hline$\left[0_{75 k} / \pm 70_{15 k}\right]_{6}$ & $\begin{array}{l}12.7 \\
25.4 \\
50.8\end{array}$ & $\begin{array}{l}0.53 \\
1.1 \\
2.1\end{array}$ & $\begin{array}{l}10.8 \\
13.2 \\
10.1\end{array}$ & $\begin{array}{l}26.4 \\
23.1 \\
22.9\end{array}$ & $\begin{array}{l}24.1 \\
23.1 \\
25.0\end{array}$ \\
\hline$\left[0_{30 k} / \pm 70_{6 k}\right]_{8}$ & $\begin{array}{l}12.7 \\
25.4 \\
50.8\end{array}$ & $\begin{array}{l}1.1 \\
2.2 \\
4.3\end{array}$ & $\begin{array}{c}18.1 \\
26.9 \\
9.4\end{array}$ & $\begin{array}{l}39.6 \\
30.4 \\
26.6\end{array}$ & $\begin{array}{l}36.3 \\
30.4 \\
29.1\end{array}$ \\
\hline$\left[0_{6 k} / \pm 45_{15 k}\right]_{10}$ & $\begin{array}{l}12.7 \\
25.4\end{array}$ & $\begin{array}{l}1.1 \\
2.2\end{array}$ & $\begin{array}{l}9.1 \\
4.5\end{array}$ & $\begin{array}{l}30.7 \\
31.6\end{array}$ & $\begin{array}{l}28.1 \\
31.5\end{array}$ \\
\hline$\left[0_{36 k} / \pm 45_{15 k}\right]_{6}$ & $\begin{array}{l}12.7 \\
25.4\end{array}$ & $\begin{array}{l}1.1 \\
2.2\end{array}$ & $\begin{array}{c}15.1 \\
6.1\end{array}$ & $\begin{array}{l}30.9 \\
28.0\end{array}$ & $\begin{array}{l}28.3 \\
28.0\end{array}$ \\
\hline
\end{tabular}


TABLE 4--Effect of test method on strength.

\begin{tabular}{|c|c|c|c|c|}
\hline Material & $\begin{array}{c}\text { Test } \\
\text { method }\end{array}$ & $\begin{array}{l}\text { Number of } \\
\text { specimens }\end{array}$ & $\begin{array}{c}\text { C.V. } \\
\% \\
\end{array}$ & $\begin{array}{c}\text { Average } \\
\text { strength, } \mathrm{MPa}\end{array}$ \\
\hline 12-layer plain weave & $\begin{array}{c}\text { HLM } \\
4 \mathrm{~PB}\end{array}$ & $\begin{array}{l}5 \\
8\end{array}$ & $\begin{array}{l}2.73 \\
8.41\end{array}$ & $\begin{array}{l}24.3 \\
25.1\end{array}$ \\
\hline 16-layer plain weave & $\begin{array}{c}\text { HLM } \\
\text { 4PB }\end{array}$ & $\begin{array}{l}6 \\
8\end{array}$ & $\begin{array}{l}22.8 \\
13.7\end{array}$ & $\begin{array}{l}20.6 \\
26.1\end{array}$ \\
\hline 12 -layer $5 \mathrm{H}$ weave $(3 \mathrm{k})$ & $\begin{array}{c}\text { HLM } \\
\text { 4PB }\end{array}$ & $\begin{array}{l}6 \\
9\end{array}$ & $\begin{array}{l}19.8 \\
13.3\end{array}$ & $\begin{array}{l}35.0 \\
34.8\end{array}$ \\
\hline 12-layer $5 \mathrm{H}$ weave (6k) & $\begin{array}{c}\text { HLM } \\
4 \mathrm{~PB}\end{array}$ & $\begin{array}{l}6 \\
9\end{array}$ & $\begin{array}{l}6.79 \\
20.9\end{array}$ & $\begin{array}{l}31.5 \\
32.6\end{array}$ \\
\hline 25-ply AS4/8551-7 & $\begin{array}{c}\text { HLM } \\
\text { 4PB }\end{array}$ & $\begin{array}{l}7 \\
6\end{array}$ & $\begin{array}{l}4.31 \\
13.6\end{array}$ & $\begin{array}{l}57.0 \\
46.0\end{array}$ \\
\hline$\left[0_{6 k} / \pm 45_{15 k}\right]_{10}$ & $\begin{array}{c}\text { HLM } \\
4 \mathrm{~PB}\end{array}$ & $\begin{array}{l}5 \\
2\end{array}$ & $\begin{array}{l}6.10 \\
17.2\end{array}$ & $\begin{array}{l}30.2 \\
29.6\end{array}$ \\
\hline$\left[0_{36 k} / \pm 45_{15 k}\right]_{6}$ & $\begin{array}{c}\text { HLM } \\
4 \mathrm{~PB}\end{array}$ & $\begin{array}{l}5 \\
2\end{array}$ & $\begin{array}{l}9.23 \\
0.80\end{array}$ & $\begin{array}{l}29.1 \\
25.6\end{array}$ \\
\hline
\end{tabular}

TABLE 5--Average strengths for 2D materials

\begin{tabular}{|c|c|c|c|c|c|}
\hline Material & $\begin{array}{l}\text { Number } \\
\text { of tests }\end{array}$ & $\begin{array}{c}\text { C.V., } \\
\%\end{array}$ & $\begin{array}{c}\text { Average } \\
\text { strength, } \\
\mathrm{MPa}\end{array}$ & $\begin{array}{l}\text { Low } \\
\text { value, } \\
\mathrm{MPa}\end{array}$ & $\begin{array}{c}\text { High } \\
\text { value, } \\
\text { MPa }\end{array}$ \\
\hline $\begin{array}{l}\text { Tapes } \\
\text { 24-ply AS4/3501-6 } \\
\text { 48-ply AS4/3501-6 }\end{array}$ & $\begin{array}{c}8 \\
10\end{array}$ & $\begin{array}{l}12.7 \\
32.0\end{array}$ & $\begin{array}{l}68.8 \\
25.1\end{array}$ & $\begin{array}{l}56.5 \\
15.5\end{array}$ & $\begin{array}{l}80.0 \\
43.3\end{array}$ \\
\hline $\begin{array}{l}\text { 25-ply AS4/8551-7 } \\
48 \text {-ply AS } 4 / 8551-7\end{array}$ & $\begin{array}{c}13 \\
6\end{array}$ & $\begin{array}{l}13.9 \\
5.62\end{array}$ & $\begin{array}{l}51.9 \\
46.7\end{array}$ & $\begin{array}{l}38.0 \\
43.0\end{array}$ & $\begin{array}{l}60.4 \\
49.8\end{array}$ \\
\hline $\begin{array}{c}\text { Fabrics } \\
\text { 12-layer plain weave } \\
\text { 16-layer plain weave } \\
\text { 12-layer } 5 \mathrm{H} \text { weave }(3 \mathrm{k}) \\
\text { 12-layer } 5 \mathrm{H} \text { weave }(6 \mathrm{k})\end{array}$ & $\begin{array}{l}13 \\
14 \\
15 \\
14\end{array}$ & $\begin{array}{l}6.85 \\
20.4 \\
15.5 \\
14.9\end{array}$ & $\begin{array}{l}24.8 \\
23.7 \\
34.9 \\
32.8\end{array}$ & $\begin{array}{l}22.7 \\
14.1 \\
25.0 \\
27.8\end{array}$ & $\begin{array}{l}29.3 \\
30.7 \\
42.7 \\
48.6\end{array}$ \\
\hline 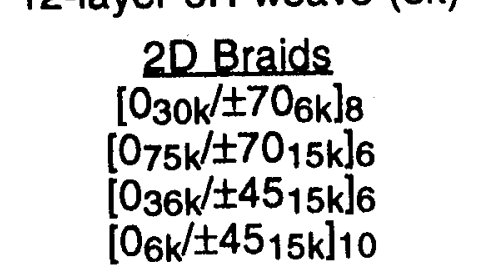 & $\begin{array}{r}11 \\
11 \\
7 \\
7\end{array}$ & $\begin{array}{l}20.4 \\
11.8 \\
9.84 \\
8.61\end{array}$ & $\begin{array}{l}32.4 \\
24.5 \\
28.1 \\
30.1\end{array}$ & $\begin{array}{c}22 \\
20.5 \\
25.5 \\
26.0\end{array}$ & $\begin{array}{l}43.5 \\
29.0 \\
33.2 \\
33.2\end{array}$ \\
\hline
\end{tabular}


TABLE 6--Bending moment at failure.

\begin{tabular}{|c|c|c|}
\hline Material & $\begin{array}{c}\text { C.V. } \\
\%\end{array}$ & $\frac{M}{w t}, \frac{\mathrm{N}}{\mathrm{mm}}$ \\
\hline \multicolumn{3}{|l|}{ 3D weaves } \\
\hline Through-the-thickness orthogonal interlock (OS-1) & 9.5 & 74.7 \\
\hline Through-the-thickness orthogonal interlock (OS-2) & & \\
\hline Through-the-thickness angle interlock (TS-1) & 10.1 & 91.7 \\
\hline Through-the-thickness angle interlock (TS-2) & 13.3 & 86.0 \\
\hline Layer-to-layer angle interlock (LS-1) & 9.4 & 83.0 \\
\hline Layer-to-layer angle interlock (LS-2) & 4.5 & 86.5 \\
\hline 3D Braid & 7.0 & 54.1 \\
\hline \multicolumn{3}{|l|}{ Tapes } \\
\hline $\begin{array}{l}\text { 24-ply AS4/3501-6 } \\
\text { 48-ply AS4/3501-6 }\end{array}$ & $\begin{array}{l}12.6 \\
34.0\end{array}$ & $\begin{array}{l}320.5 \\
160.0\end{array}$ \\
\hline $\begin{array}{l}\text { 25-ply AS4/8551-7 } \\
48 \text {-ply AS4/8551-7 }\end{array}$ & $\begin{array}{r}11.8 \\
5.6\end{array}$ & $\begin{array}{l}221.0 \\
265.1\end{array}$ \\
\hline \multicolumn{3}{|l|}{ 2D fabric } \\
\hline 12-layer plain weave & 7.5 & 108.6 \\
\hline 16-layer plain weave & 16.5 & 120.7 \\
\hline 12-layer $5 \mathrm{H}$ weave $(3 \mathrm{k})$ & 14.0 & 164.6 \\
\hline 12-layer $5 \mathrm{H}$ weave $(6 \mathrm{k})$ & 16.2 & 162.8 \\
\hline \multicolumn{3}{|l|}{$2 \mathrm{D}$ braids } \\
\hline$\left[0_{36 \mathrm{k}} / \pm 45_{15 \mathrm{k}}\right]_{6}$ & 5.8 & 139.1 \\
\hline$\left[0_{6 \mathrm{k}} / \pm 45_{15 \mathrm{k}}\right]_{10}$ & 10.8 & 155.7 \\
\hline
\end{tabular}




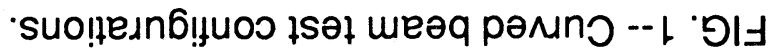
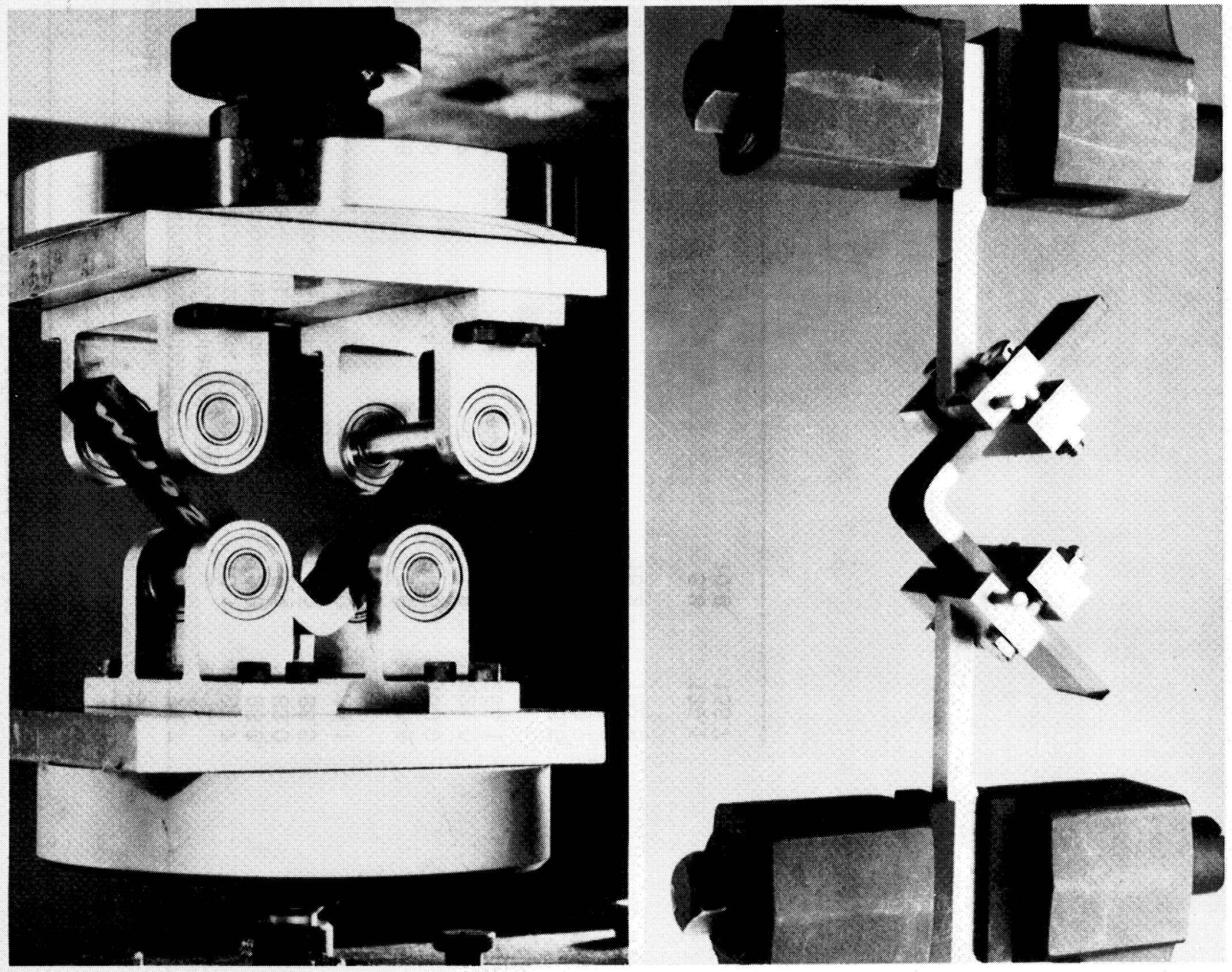

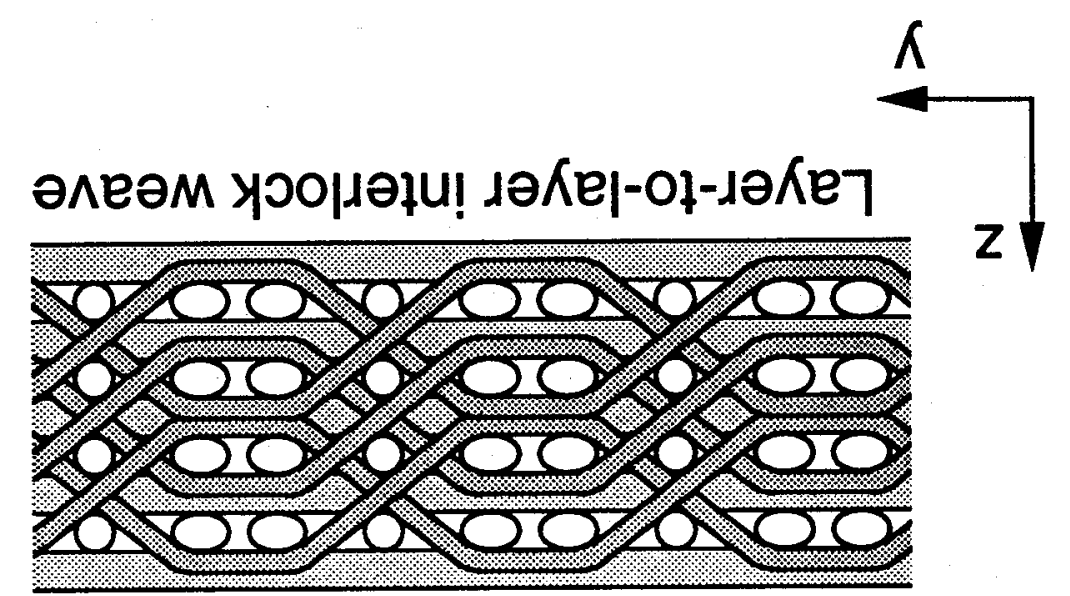

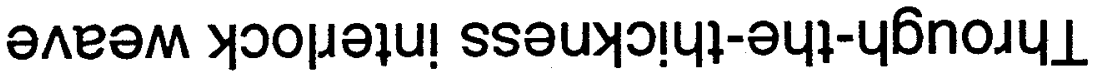

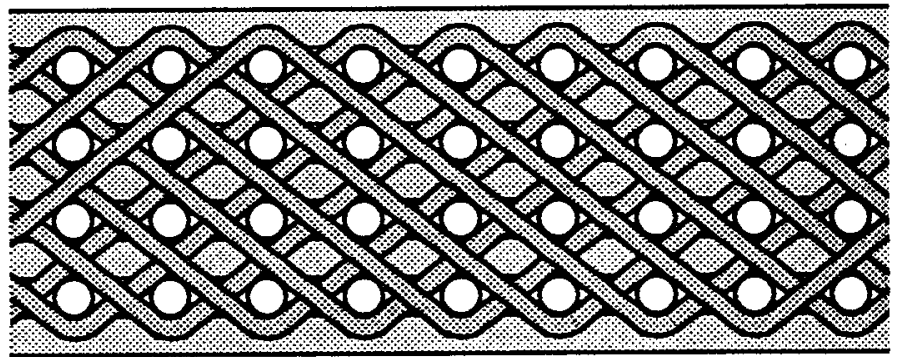

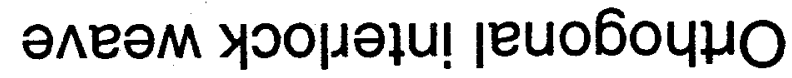

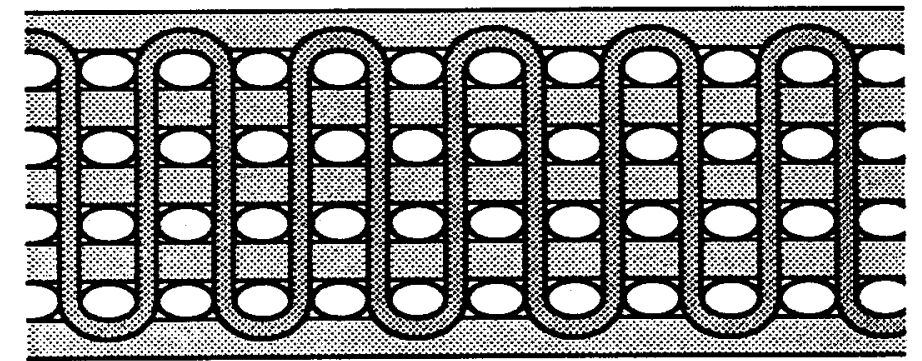

$\theta$ 'əןбure
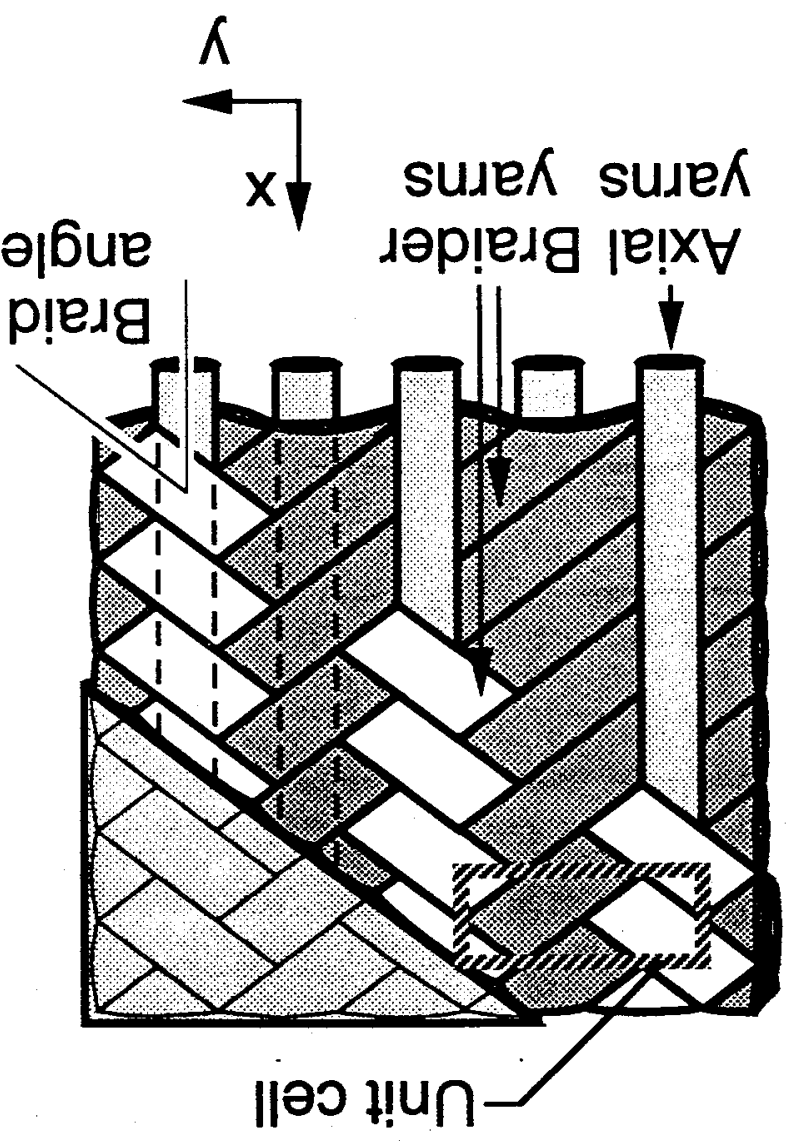

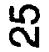

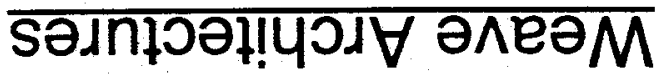




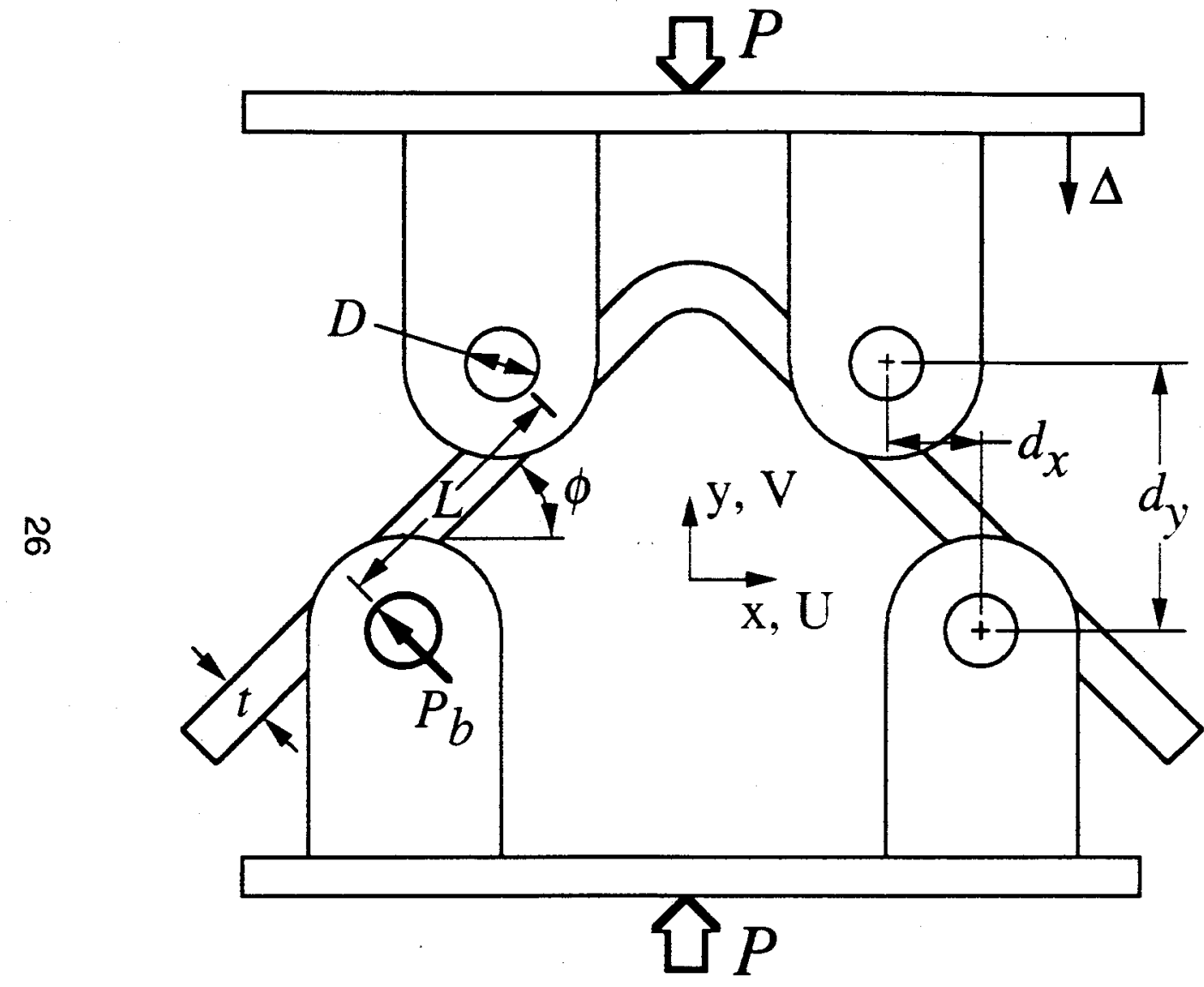

a) Four-point-bend test

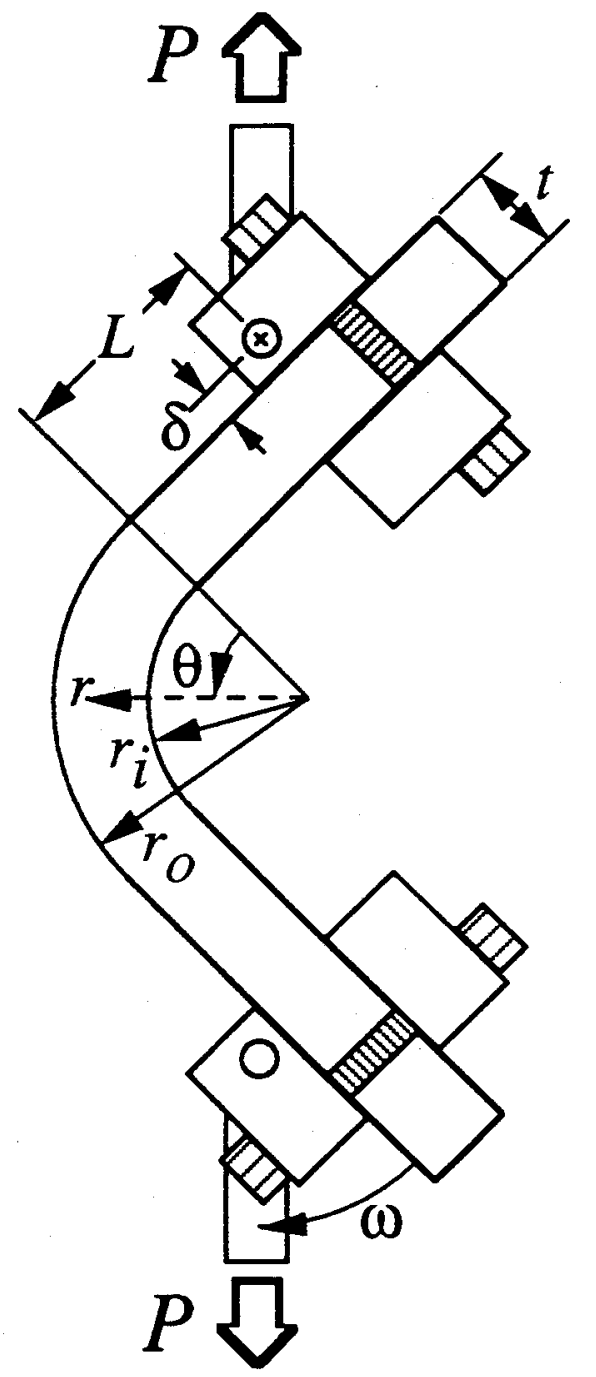

b) Hinged loading mechanism test

FIG. 3--Schematic of test configurations. 


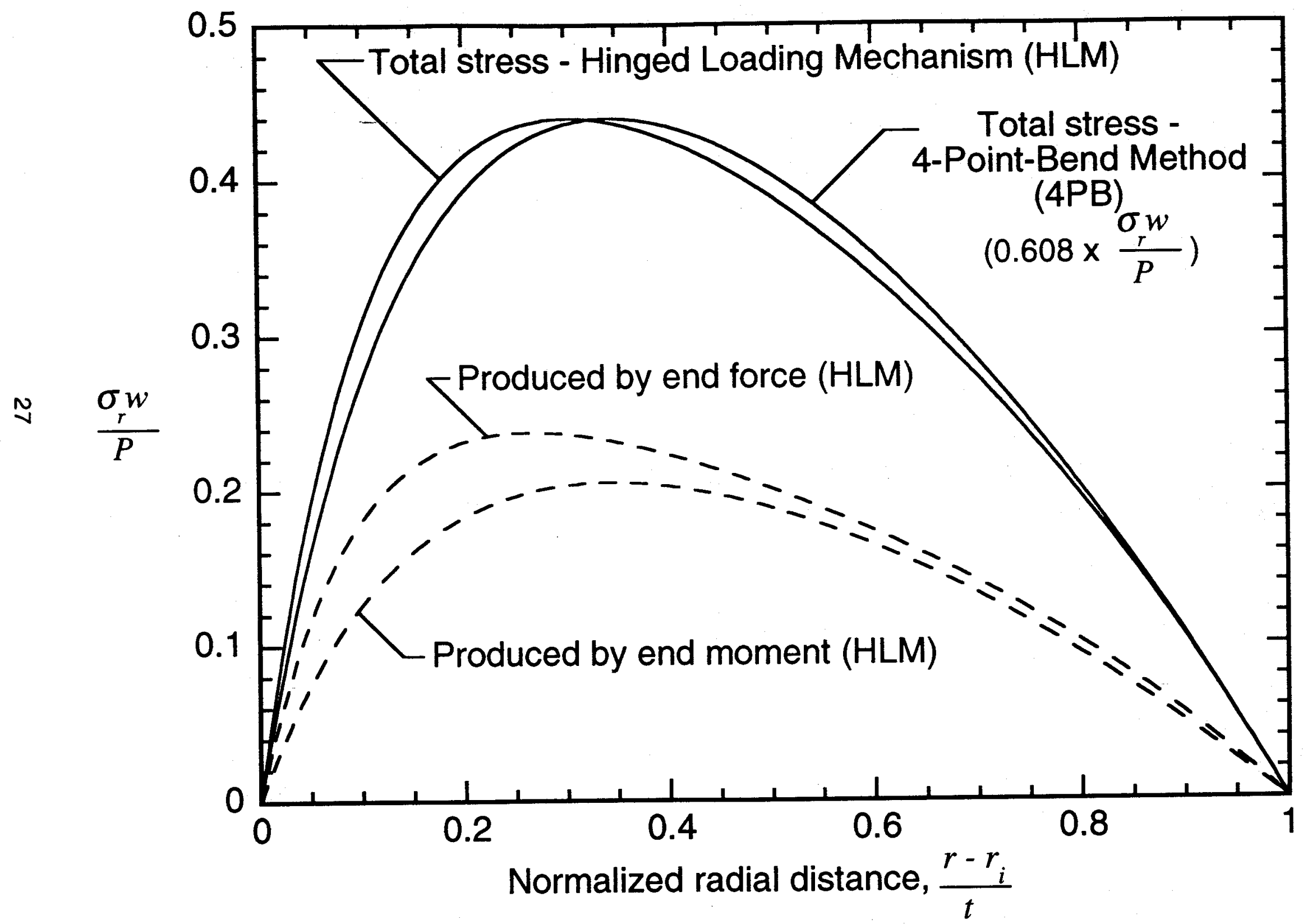

FIG. 4--Radial stress distributions produced by the two test methods. 


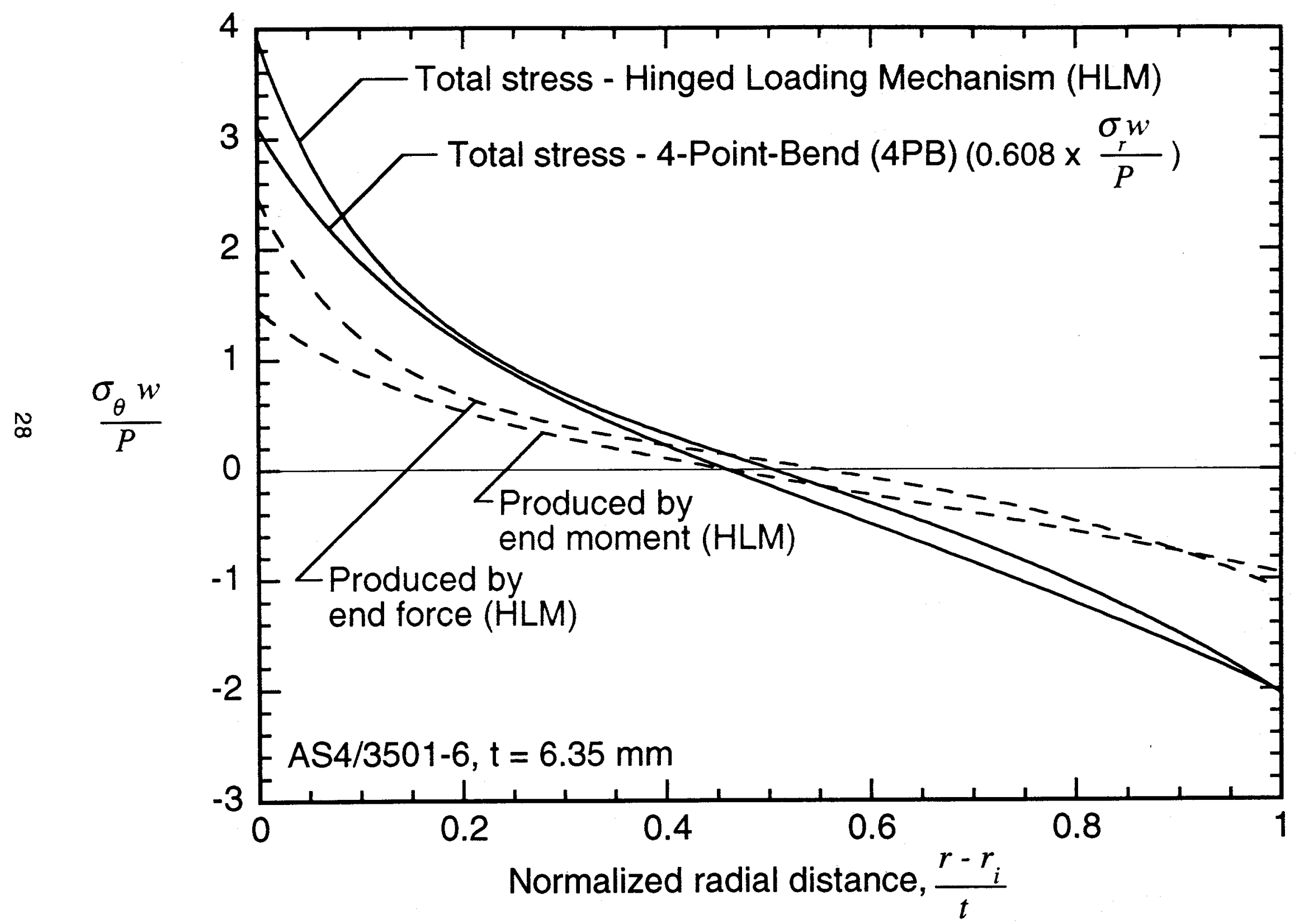

FIG. 5--Circumferential stress distributions produced by the two test methods. 


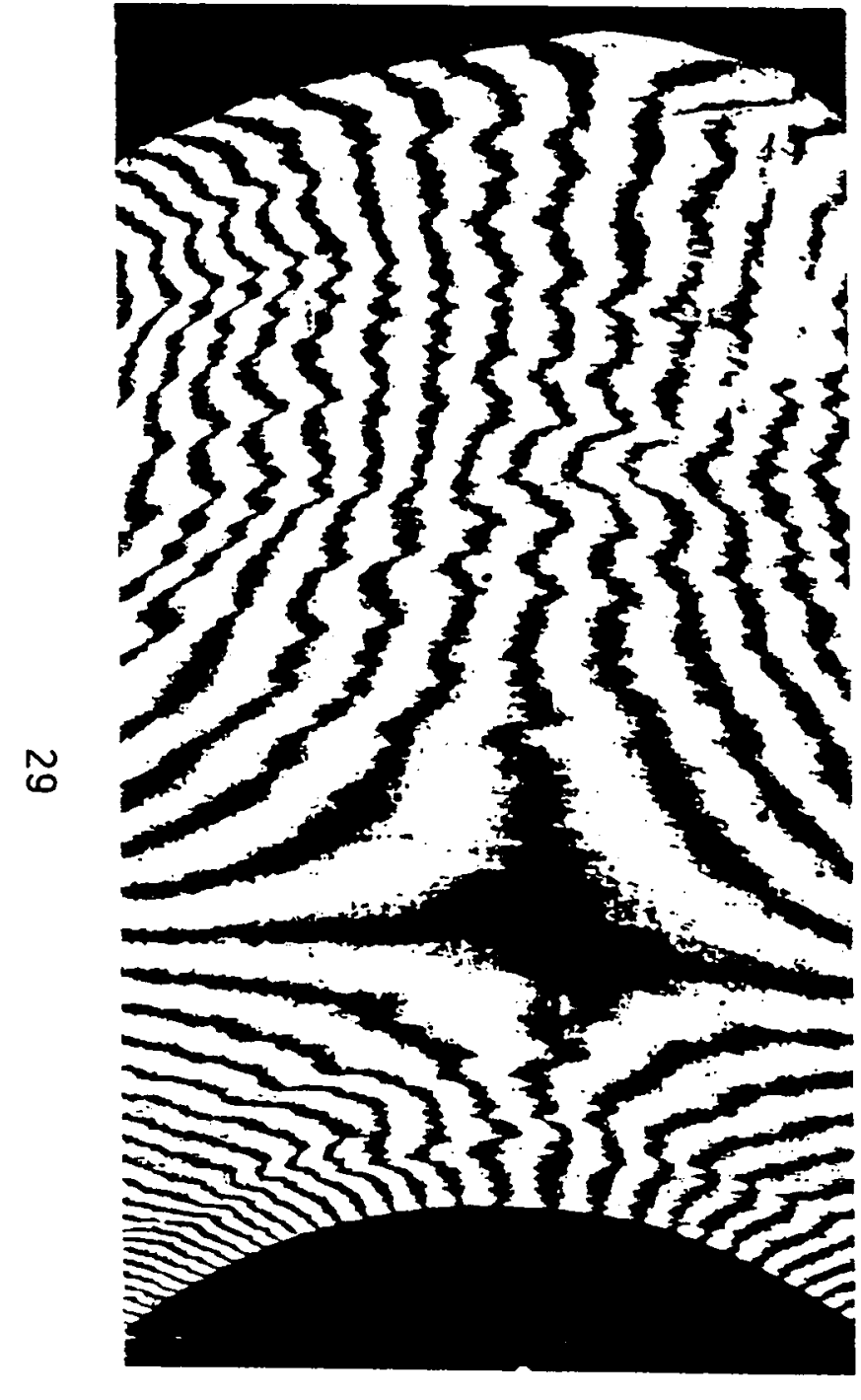

U field

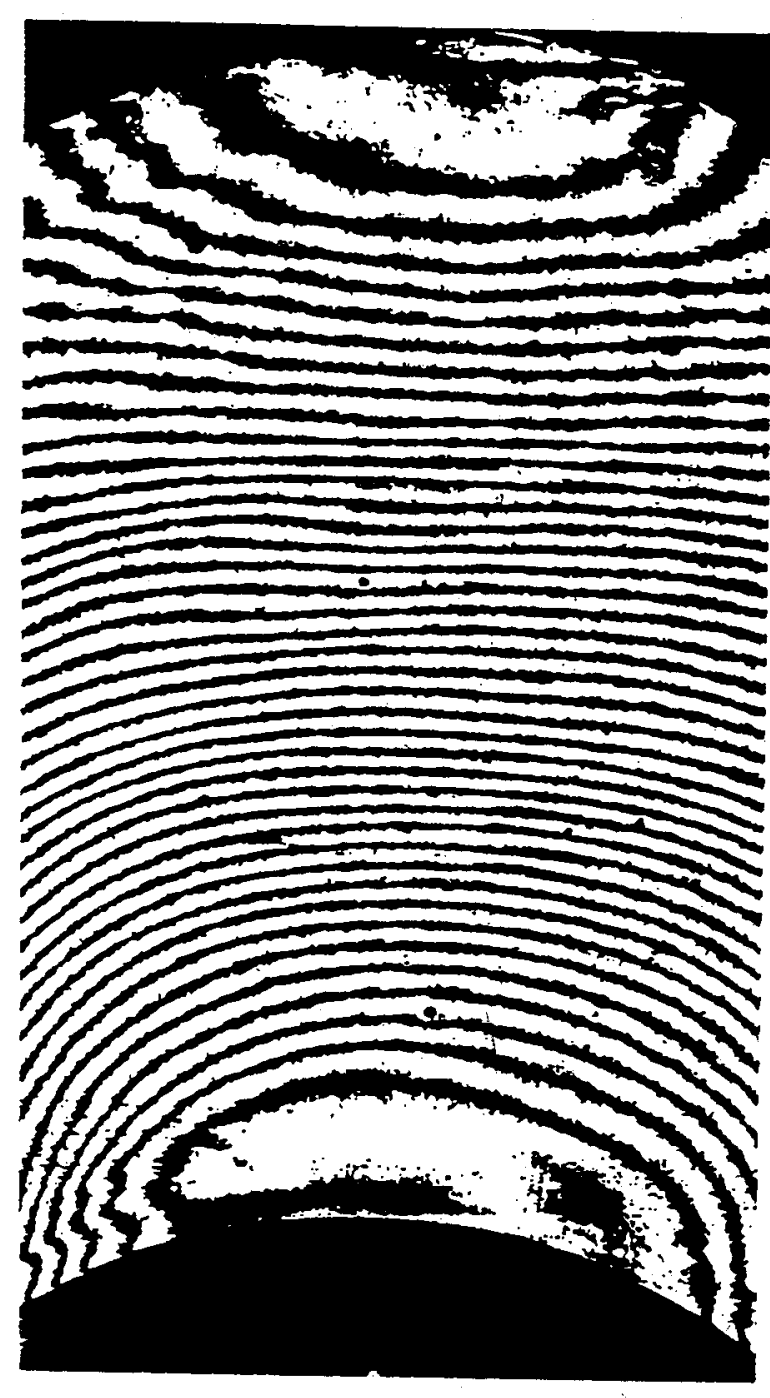

$V$ field

FIG. 6--Moiré fringe patterns for a 48-ply AS4/3501-6 specimen.

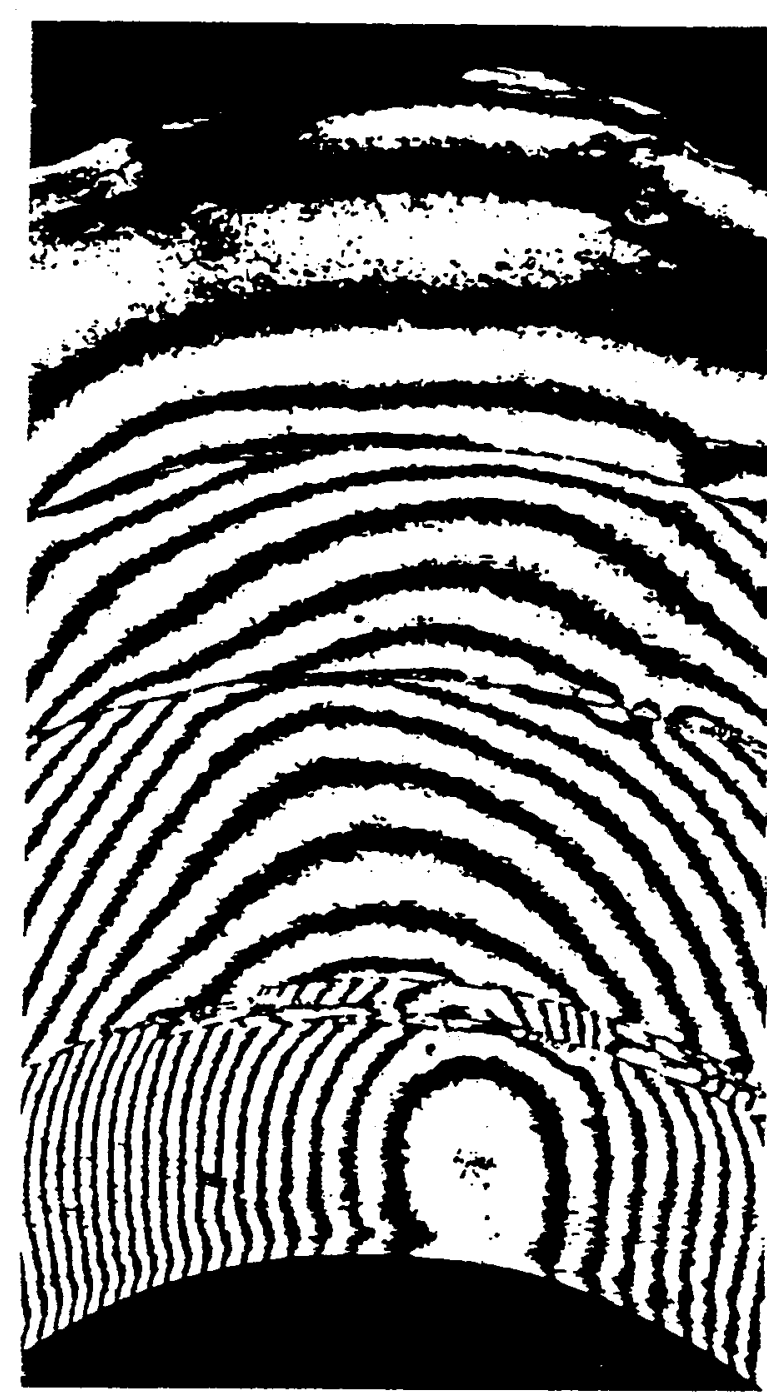

$V$ field after failure 


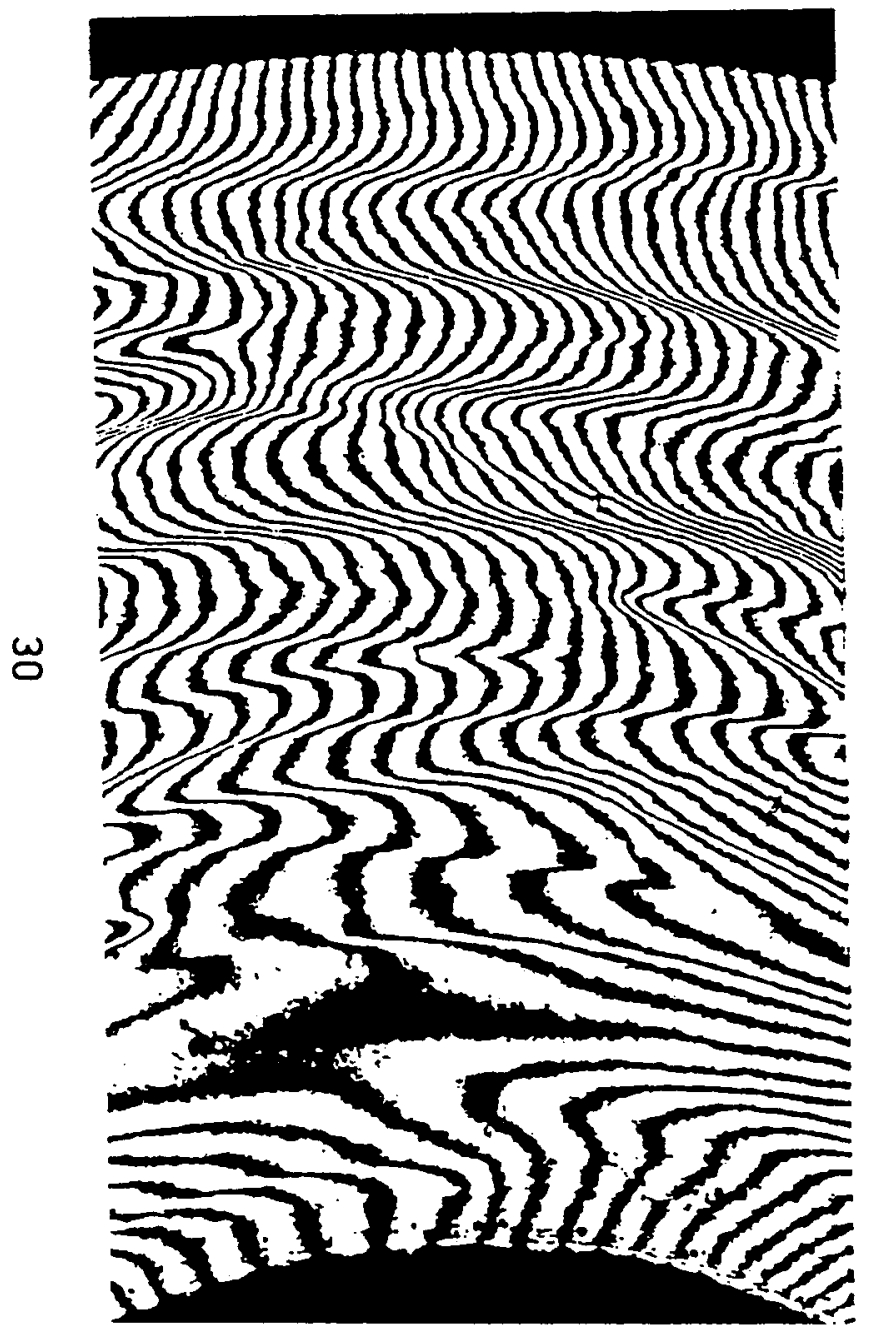

U field

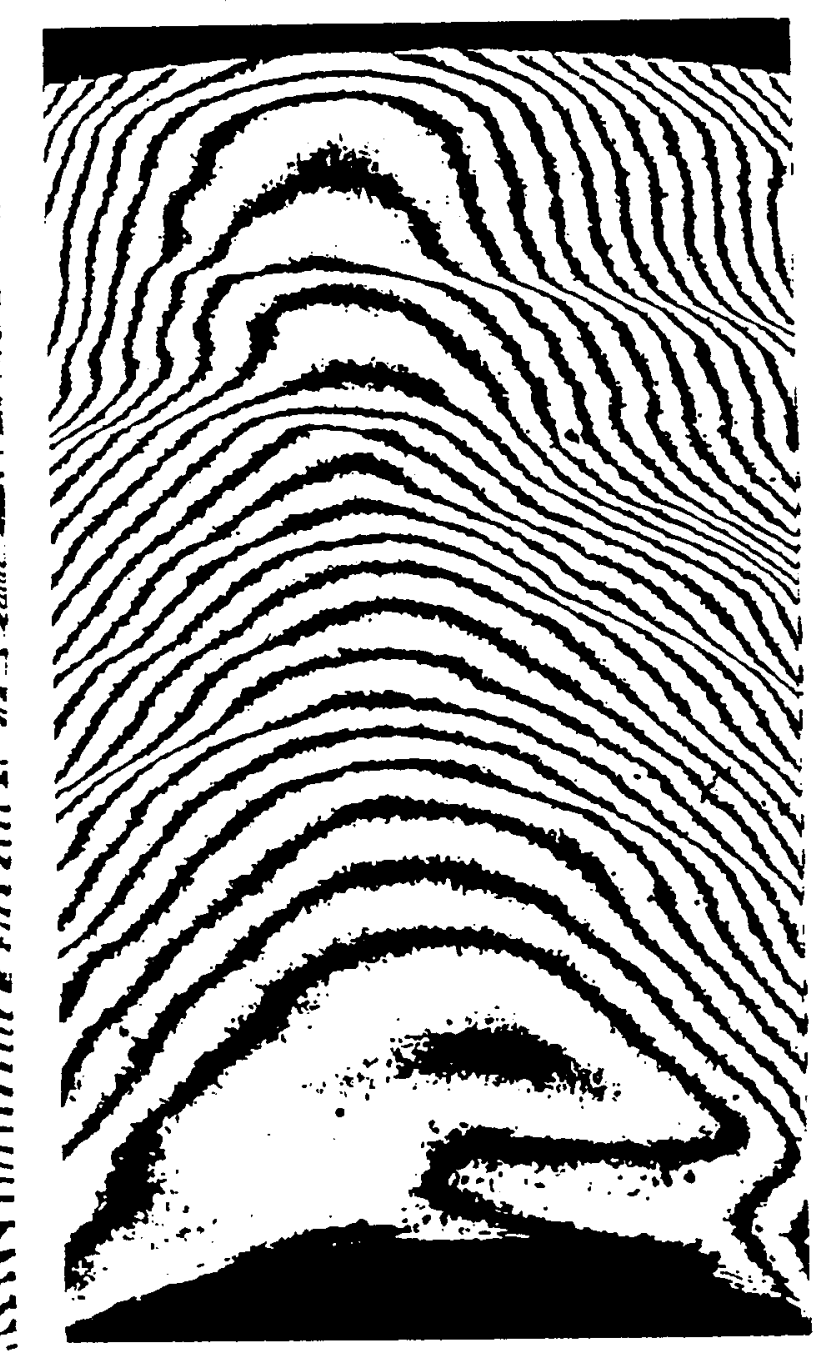

$V$ field

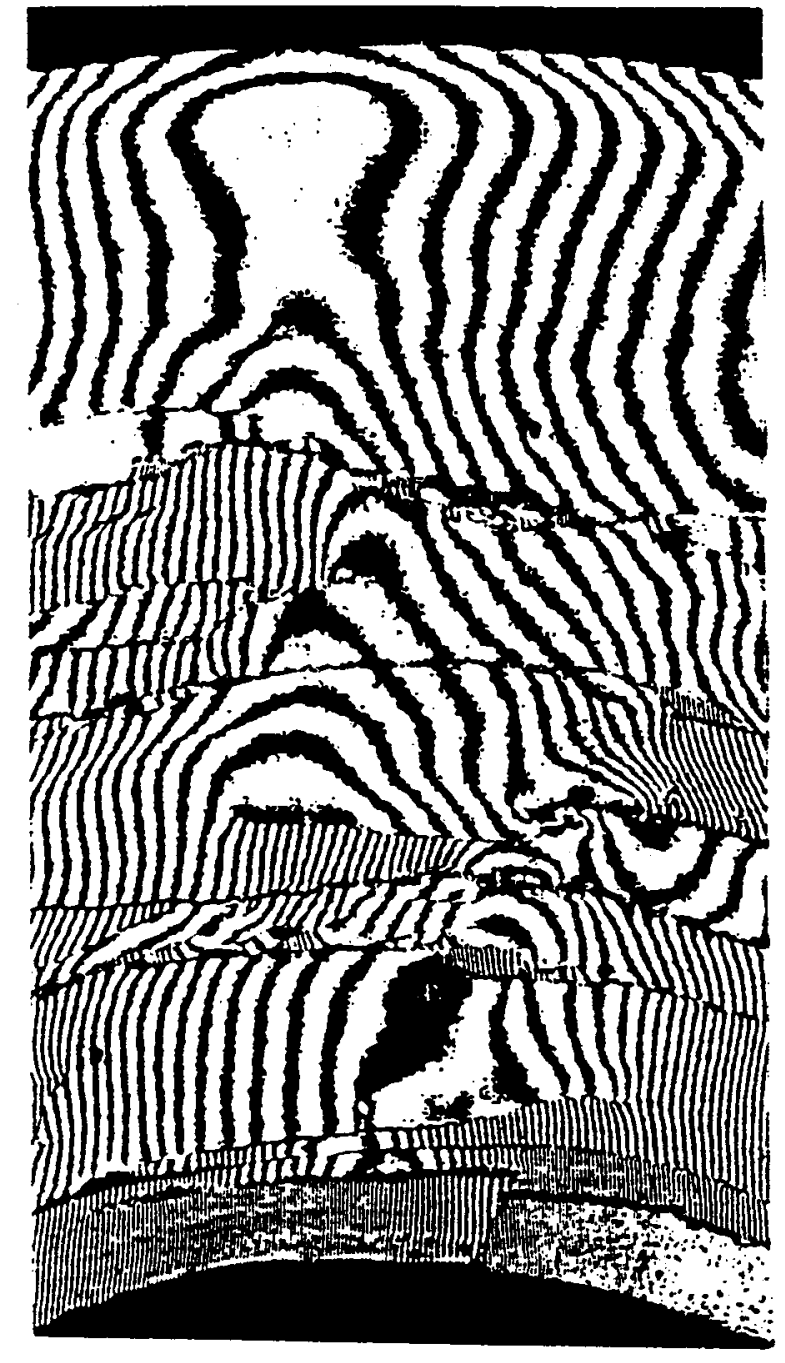

$V$ field after failure

FIG. 7--Moiré fringe patterns for a 2D triaxial $\left[\mathrm{O}_{6 \mathrm{k}} / \pm 45_{15 k}\right]_{10}$ braid. 


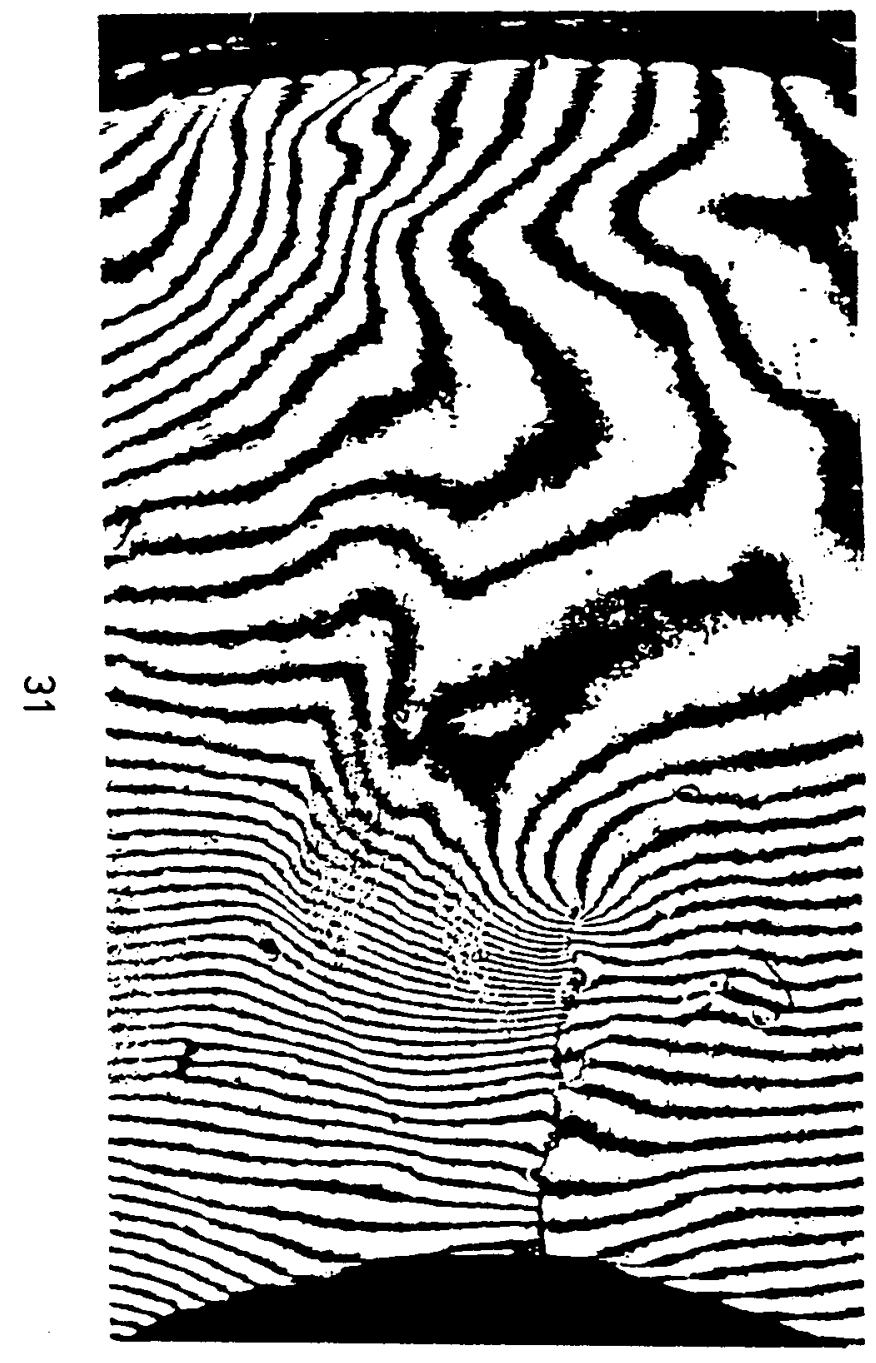

U field

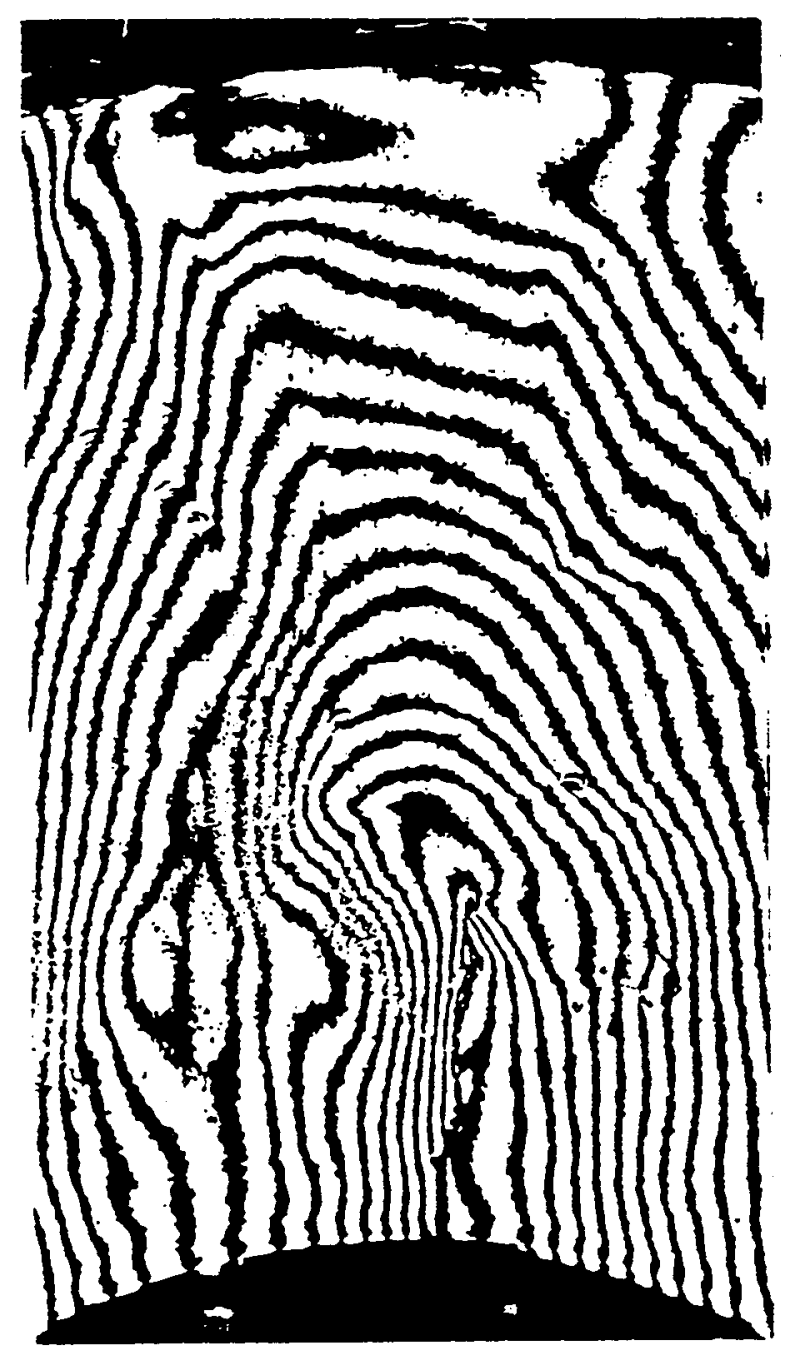

$V$ field

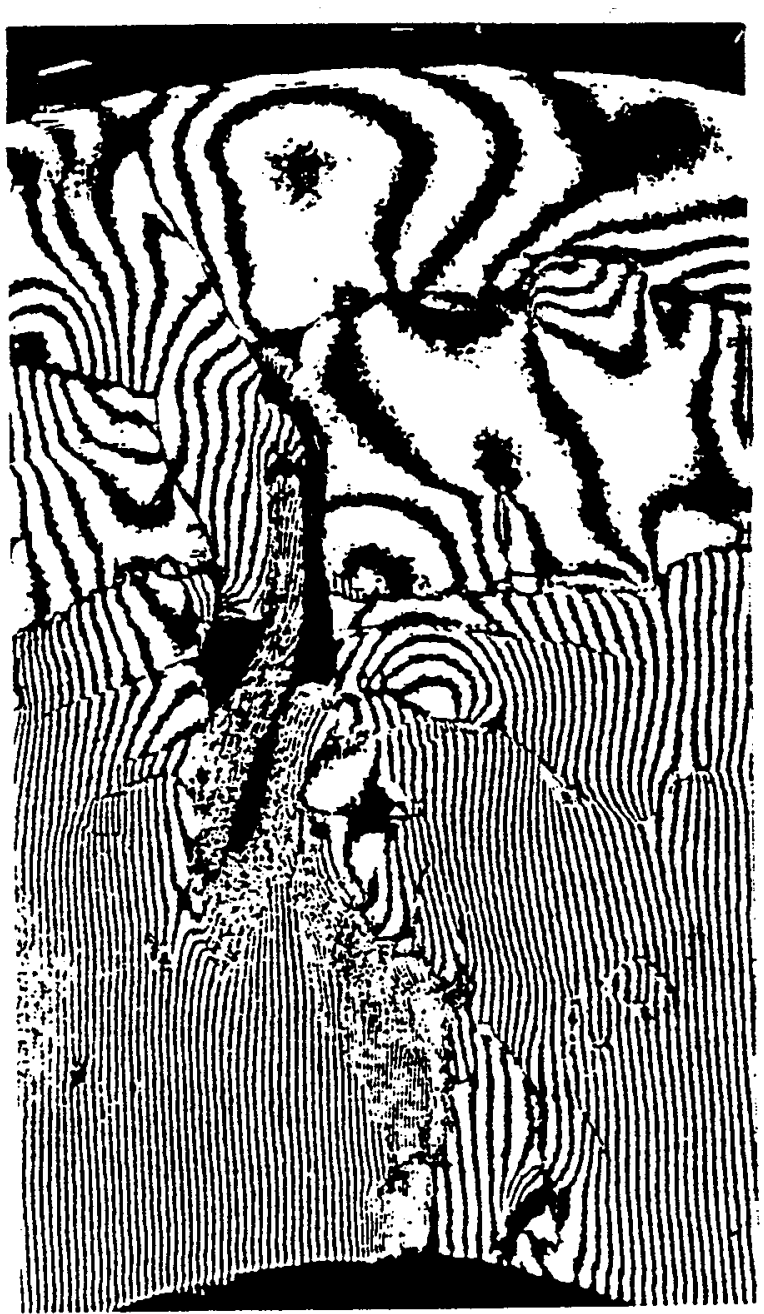

$V$ field after failure

FIG. 8--Moiré fringe patterns for a through-the-thickness orthogonal interlock weave (OS-1). 


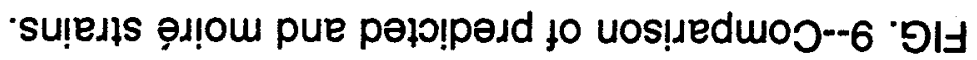

wu 'uo!̣!sod je!pey

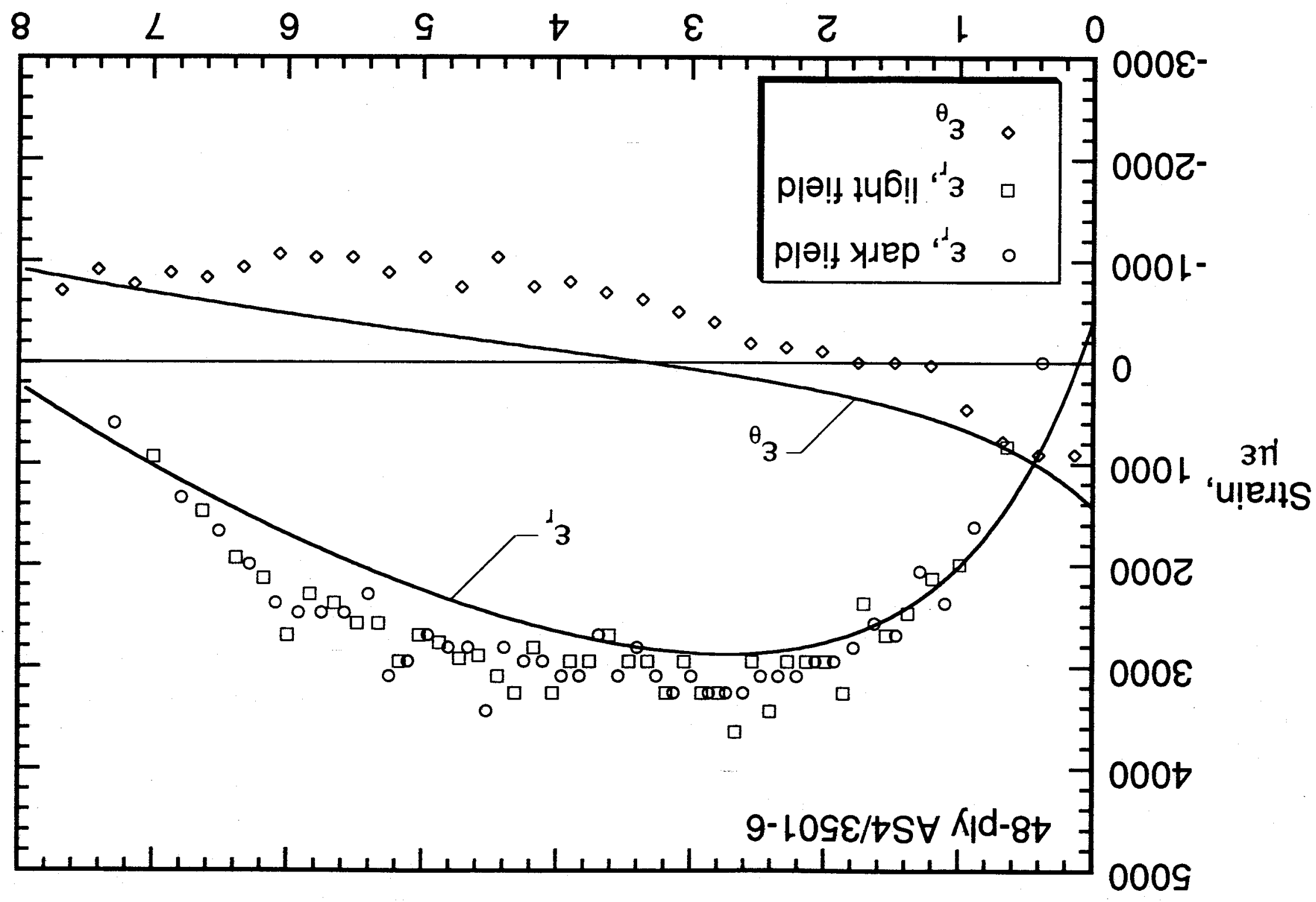




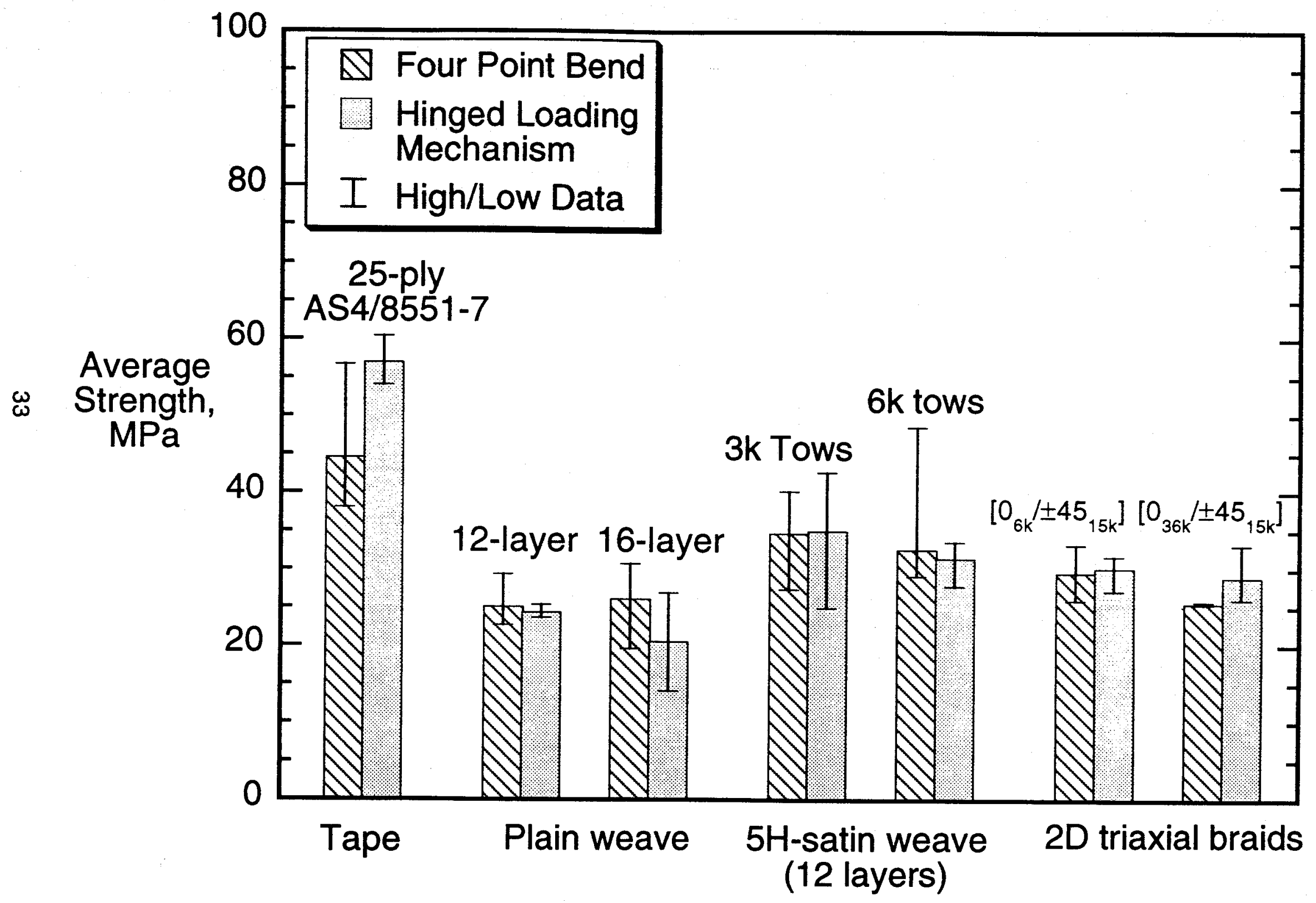

FIG. 10--Comparison of strengths for the two test methods. 


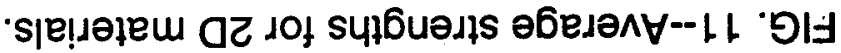

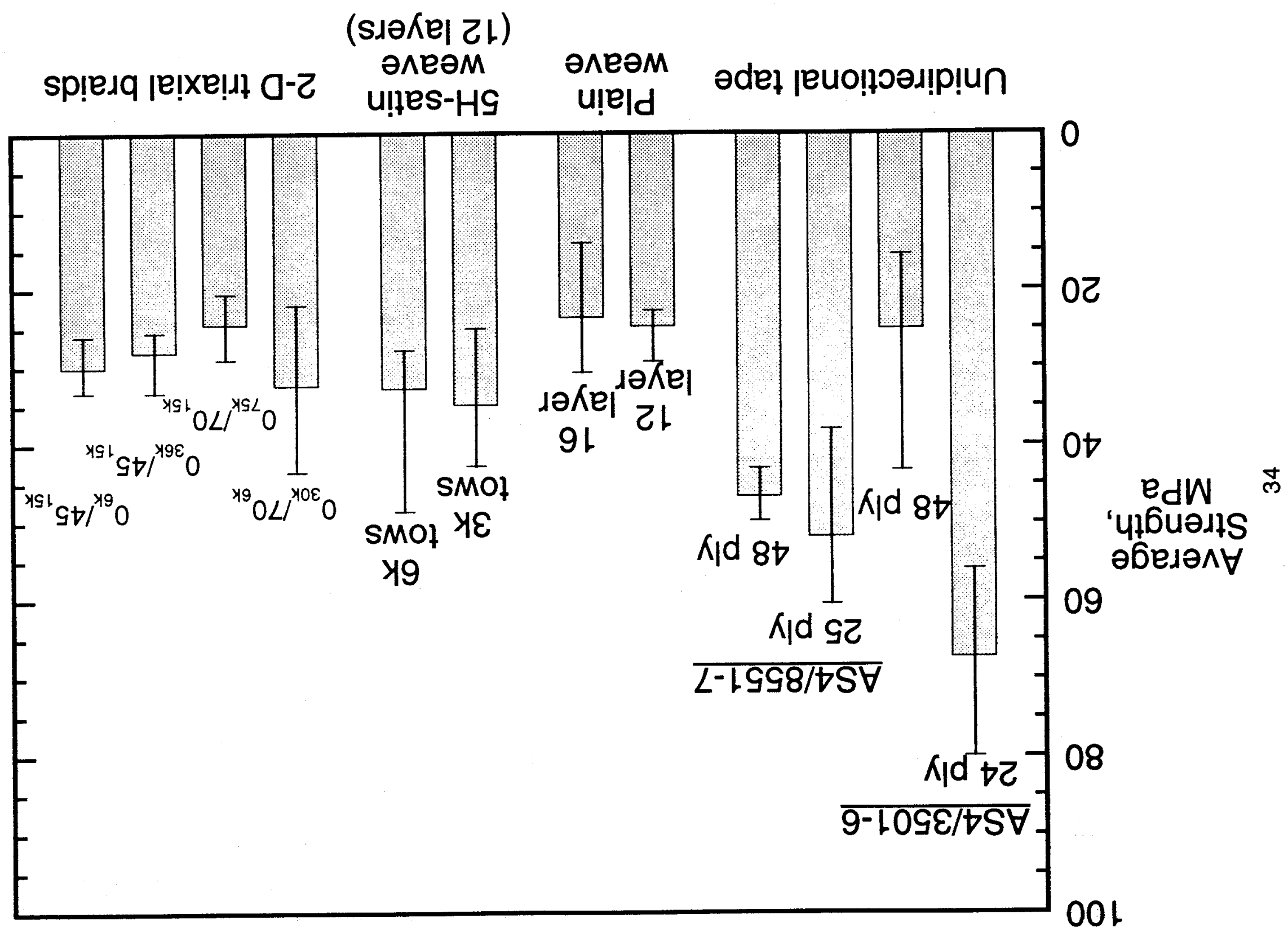




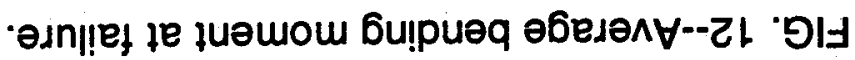

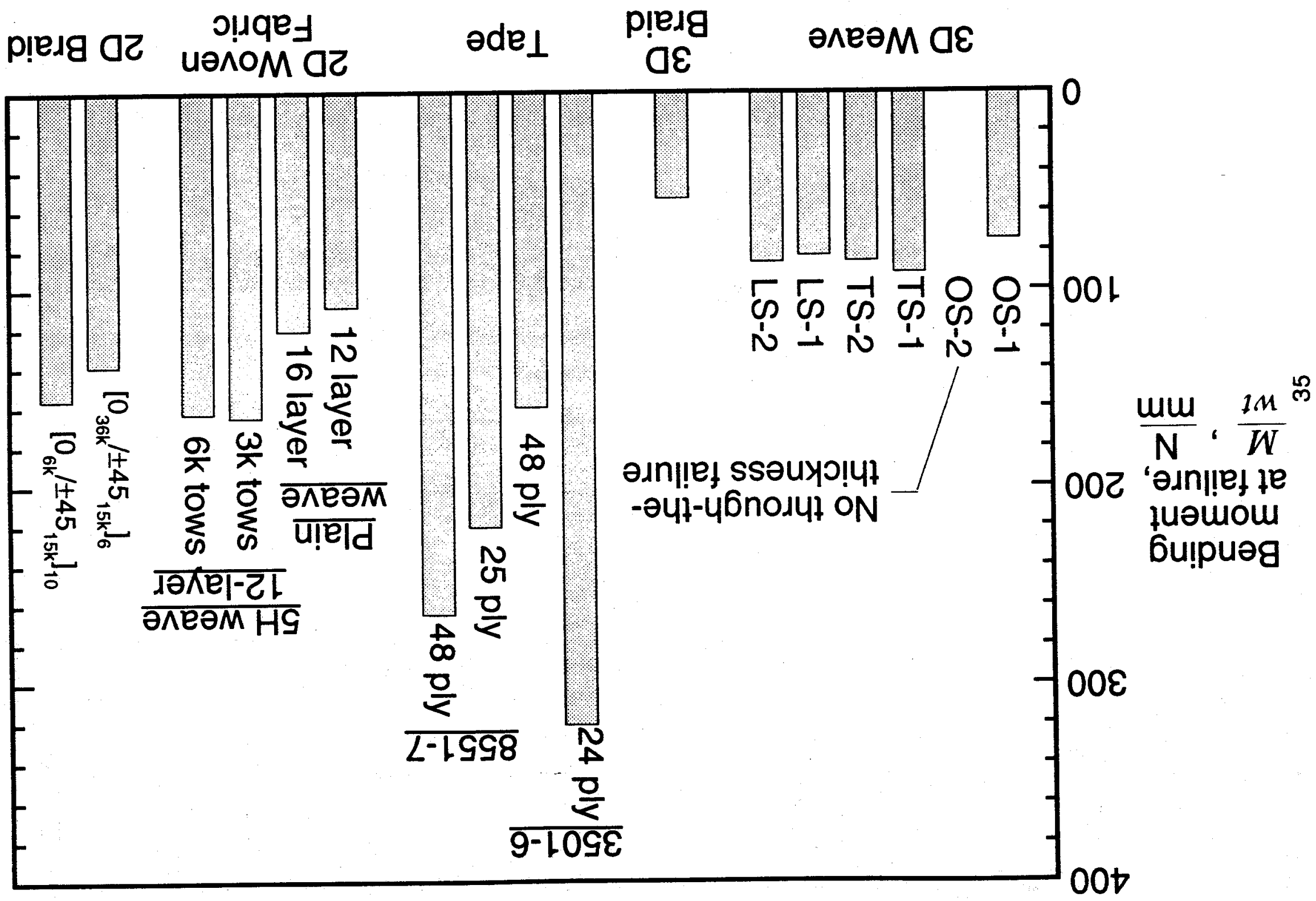




\begin{tabular}{|c|c|c|c|c|}
\hline REPORT & \multicolumn{2}{|c|}{ DOCUMENTATION PAGE } & & $\begin{array}{l}\text { Form Approved } \\
\text { OMB No. 0704-0188 }\end{array}$ \\
\hline \multicolumn{5}{|c|}{ 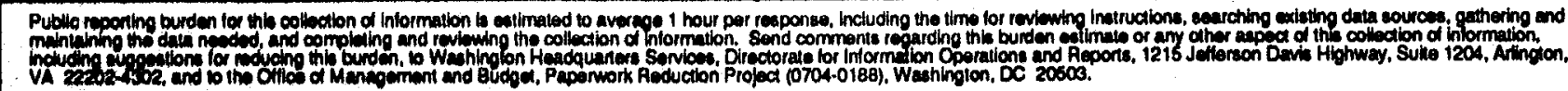 } \\
\hline 1. AG ANCV USE ONLY (LESVO b/ank) & $\begin{array}{l}\text { 2. REPORT DATE } \\
\text { May } 1994\end{array}$ & $T^{3}$ & \multicolumn{2}{|c|}{$\begin{array}{l}\text { 3. REPORT TYPE AND DATES COVERED } \\
\text { Technical Memorandum }\end{array}$} \\
\hline \multicolumn{3}{|c|}{$\begin{array}{l}\text { 4. TIFLE AND SUBTITLE } \\
\text { Through-the-Thickness Tensile Strength of Textile Composites }\end{array}$} & \multirow{2}{*}{\multicolumn{2}{|c|}{$\begin{array}{l}\text { 6. FUNOINO NUMBEAS } \\
\text { WU 505-63-50-04 }\end{array}$}} \\
\hline \multicolumn{3}{|c|}{$\begin{array}{l}\text { O. AUTHOA(\$) } \\
\text { Wade C. Jackson and Peter G. Ifju }\end{array}$} & & \\
\hline \multicolumn{2}{|c|}{$\begin{array}{l}\text { 7. PERFOAMINO OROANIZATION NAME(8) AND ADDRESS(ES) } \\
\text { NASA Langley Research Center } \\
\text { Hampton, VA } 23681-0001\end{array}$} & & \multicolumn{2}{|c|}{$\begin{array}{l}\text { 8. PERFOAMING ORGANIZATION } \\
\text { REPORT NUMBER }\end{array}$} \\
\hline \multicolumn{3}{|c|}{ 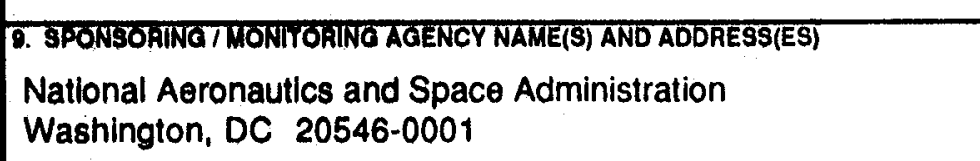 } & \multicolumn{2}{|c|}{$\begin{array}{l}\text { 10. SPONSORING / MONITORING } \\
\text { AGENCY REPORT NUMBER } \\
\text { NASA TM-109115 }\end{array}$} \\
\hline \multicolumn{5}{|c|}{$\begin{array}{l}\text { 11. SUPPLEMENTARY NOTES } \\
\text { Jackson: Langley Research Center, Hampton, VA; Ifju: University of Florida, Gainesville, Florida. Presented at } \\
\text { the ASTM 12th Symposium on Composite Materials: Testing and Design, Montreal, Canada, May 16-17, 1994. }\end{array}$} \\
\hline \multicolumn{3}{|c|}{$\begin{array}{l}\text { 12a. DISTRIBUTIONTAVAILABILITYSTATEMEENT } \\
\text { Unclassified - Unilimited } \\
\text { Subject Category - } 24\end{array}$} & \multicolumn{2}{|c|}{ 12b. DISTRIBUTION CODE } \\
\hline \multicolumn{5}{|c|}{$\begin{array}{l}\text { 13. AbsthACT (Max/mum } 200 \text { worda) } \\
\text { A serles of tests was run to characterize the through-the-thickness tensile strength for a variety of composites } \\
\text { that included } 2 D \text { and } 3 D \text { braids, } 2 D \text { and } 3 D \text { weaves, and prepreg tapes. A new test method based on a curved } \\
\text { beam was evaluated. The through-the-thickness deformations were characterized using moire interferometry. } \\
\text { Failures were significantly different between the } 2 D \text { and } 3 D \text { materials. The } 2 D \text { materials delaminated between } \\
\text { layers due to out-of-plane tensile stresses. The strength of the } 2 D \text { textile composites did not increase relative to } \\
\text { the tapes. The } 3 D \text { materials failed due to the formation of radial cracks caused by high circumferential stresses } \\
\text { along the inner radius. A circumferential crack similar to the } 2 D \text { materials produced in the final failure. Final failure } \\
\text { in the } 3 D \text { materials occurred at a lower bending moment than in other materials. The early failures were caused } \\
\text { by radial crack formation rather than low through-the-thickness strength. }\end{array}$} \\
\hline \multirow{2}{*}{\multicolumn{4}{|c|}{$\begin{array}{l}\text { 19. SUEJECT TEAMs } \\
\text { Composite material; Carbon epoxy; Textile composites; Braids; Weaves; } \\
\text { Through-the thickness tensile strength; Curved beam; Delamination; } \\
\text { Moire ilnterferometry }\end{array}$}} & $\begin{array}{l}\text { 15. NUMBER OF PAGES } \\
36\end{array}$ \\
\hline & & & & $\begin{array}{l}\text { 16. PRICE CODE } \\
\mathrm{A} 03\end{array}$ \\
\hline $\begin{array}{l}\text { 17. SECURITY CLAGSIFICATION } \\
\text { OF REPORT } \\
\text { Unclassified }\end{array}$ & $\begin{array}{l}\text { 18. GECUAITY CLASSIFICATION } \\
\text { Of THIS PAGE } \\
\text { Unclassified }\end{array}$ & $\begin{array}{l}\text { 19. SECU } \\
\text { OFAB }\end{array}$ & ATION & 20. LIMTAATION OF ABSTAACT \\
\hline
\end{tabular}

